\title{
Księgozbiory domowe inteligencji i ziemian w Galicji (1795-1914)
}

P owszechnym zjawiskiem w okresie zaborów było gromadzenie książek szczególnie przez inteligencję i ziemian. W jego wyniku powstały liczne księgozbiory domowe. Zainteresowania nimi ze strony autora niniejszego opracowania doprowadziły do poznania tych zbiorów pod względem ilości, formy i treści, losu, także w aspekcie społecznym (inteligencja, ziemianie). Pominięto księgarzy, antykwariuszy, drukarzy, wydawców i bibliotekarzy, biblioteki fundacyjne, np. Ossolińskiego i tym podobnych - prócz tych, którzy mieli własne księgozbiory (w domu). Ograniczono się do Galicji - w tym zakresie, gdy zbiory były gromadzone na tej ziemi, a także w przypadku, jeżeli zostały podarowane instytucjom na niej znajdującym się przez właścicieli zamieszkałych w innych częściach kraju.

\section{1. Źródła i metoda pracy. Stan badań}

Opracowanie to opiera się na czterech zasadniczych typach źródeł:

1. na inwentarzach i katalogach bibliotecznych, zawartych zwłaszcza w zbiorach rękopiśmiennych Biblioteki Zakładu Narodowego im. Ossolińskich;

2. opracowaniach dotyczacych księgozbiorów domowych inteligencji i ziemian, a zwłaszcza na pracach powstałych $w$ wyniku badań nad tymi zbiorami;

3. na opracowaniach typu encyklopedycznego; wreszcie

4. na pracach magisterskich napisanych w różnych ośrodkach uczelnianych.

Cenniejszymi źródłami informacji o zbiorach są spisy księgozbiorów w postaci inwentarzy i katalogów bibliotecznych. Takimi są prace: Zdzisława Staniszewskiego: Inwentarze biblioteczne wieku XVII $i$ XVIII w rękopisach Ossolineum i Władysławy Jabłońskiej Inwentarze i katalogi biblioteczne $w$ zbiorach rękopiśmiennych Biblioteki Zakładu Narodowego im. Ossolińskich. ${ }^{1}$ Pierwsza z nich dotyczy czasów sprzed XIX wieku, stąd też z konieczności okazała się tu mało przydatna. Jeżeli cho- 
dzi o druga pracę, zawiera spis 79 rękopisów w formie katalogów i inwentarzy dawnych zbiorów. Z tego 47 dotyczy księgozbiorów domowych. Materiały te pozwoliły na wgląd w same rękopisy, które znajdują się w Bibliotece im. Ossolinskich we Wroclawiu.

Następnym przewodnikiem po źródłach o zbiorach stała się Bibliografia inwentarzy $i$ katalogów księgozbiorów polskich $i$ zalożonych w Polsce od 1939 roku Urszuli Paszkiewicz. ${ }^{2}$ Część druga tej pracy dotyczy księgozbiorów prywatnych.

Spośród opracowań naukowych, które stanowią drugą grupę źródeł informacji, przydatnych do niniejszej pracy, godne uwagi okazały się dzieła Edwarda Chwalewika Zbiory polskie i Franciszka Radziszewskiego Wiadomość historyczno-statystyczna o znakomilszych bibliotekach. Można było w nich znaleźć informacje o licznych kolekcjach domowych. Niestety, są w większości zbyt ogólnikowe, aby były w pełni satysfakcjonujace.

Należy tu wymienić także prace, które powstały współcześnie jako wynik badań nad księgozbiorami. Nas tu interesuja, rzecz zrozumiała, te, które przynajmniej w części dotyczą zbiorów funkcjonujących w Galicji w XIX i na początku XX wieku.

Kazimiera Maleczyńska w swej pracy Ksiazki i biblioteki w Polsce okresu zaborów przedstawiła niektóre księgozbiory prywatne ziemian, uczonych, pisarzy, nauczycieli, bibliotekarzy, duchowieństwa, prawników, lekarzy, inżynierów, różnych innych kręgów ludności, także emigracji, kobiet - kolekcjonerek, zbieraczy wiejskich. Zaznaczyła wyraźnie, że księgozbiory domowe badane były niewiele, głównie na marginesie biografii ich twórców. ${ }^{4}$

Józef Szocki w opracowaniu Księgozbiory domowe inteligencji i ziemian $w$ Galicji $w$ XIX i na poczalku XX wieku przedstawił sumaryczny obraz tych kolekcji. Stwierdził, ze zbiory te liczyły łącznie około miliona woluminów.

Godna uwagi ze względu na źródłowość jest publikacja Zbiory rękopisów $w$ bibliotekach $i$ muzeach $w$ Polsce, opracowana przez Danutę Kamolową przy współpracy Krystyny Muszyńskiej. ${ }^{6}$ Znalazły się w niej informacje o rękopisach w różnej formie (wykazy, spisy, listy, autografy itp.).

Przydatne tu okazały się prace badaczy, dotyczące poszczególnych księgozbiorów domowych. Cenna jest ze względu na unikatowość źródeł, które zawiera, praca M.Pawlika Katalog księgozbioru, rękopisów, dyplomów, rycin, map, atlasiow, fotografii jako tez osobistych dyplomów... 
pozostalych po śp. .ózefie Ignacym Kraszewskim. ${ }^{7}$ Katalog ten i zachowany księgozbiór opisał Jerzy Jarowiecki, stwierdzając, że księgozbiór liczył 14389 tomów oprawnych. ${ }^{8}$ Ponadto ten badacz jest autorem interesującego artykułu Księgozbiór Józefa Ignacego Kraszewskiego warszlatem pisarza i historyka."

Józef Szocki opublikował prace o księgozbiorach domowych Józefa Szujskiego i Jana Kantego Podoleckiego.

W grupie opracowań typu encyklopedycznego szczególnie bogaty $w$ informacje na temat ksieggozbiorów domowych okazał się Slownik pracowników ksiazki polskiej wraz z Suplementem.

Przydatne były tu także Encyklopedia Wiedzy o Ksiqżce i Polski Slownik Biografic:ny.

Jeśli chodzi o prace magisterskie, które również tutaj wykorzystano, posłużono się bibliografiami tych prac, opracowanymi w takich ośrodkach naukowych, jak Instytut Bibliotekoznawstwa Uniwersytetu Wrocławskiego, Katedra Bibliotekoznawstwa i Informacji Naukowej Wyzszej Szkoły Pedagogicznej w Krakowie, Katedra Bibliotekoznawstwa i Informacji Naukowej Uniwersytetu Jagiellońskiego, wreszcie Instytut Bibliotekoznawstwa i Informacji Naukowej Wyższej Szkoły Pedagogicznej w Kielcach. ${ }^{13}$ Kilkanaście $z$ nich dotyczyło różnych zbiorów.

Te wszystkie źródła w sumie umożliwiały zebranie sporo materiału. Dzięki niemu udało się sporządzić trzy wykazy ze względu na stopień kompletności informacji o tych zbiorach. Pierwszy obejmuje właścicieli księgozbiorów liczących po ok. 1000 i więcej tomów, a więc duże liczbowo zbiory (aneks 1). Zawiera on 132 nazwiska właścicieli, także ich księgozbiory domowe. Drugi zaś dotyczy zbiorów mniejszych - lącznie 13 (aneks 2).

Trzeci wykaz obejmuje 78 właścicieli i ich księgozbiory domowe, o których można było odnaleźć przynajmniej nieco informacji o profesjach właściciela i samym księgozbiorze (aneks 3 ).

W sumie udało się dotrzeć bezpośrednio lub pośrednio do 223 zbiorów. Nie o wszystkich można powiedzieć, ile mają dokładnie tomów, ponieważ często spotyka się w źródłach ich dotyczących takie określenia, jak „bogaty ksiegozbiór”, „kilkanaście tysięcy”. Takie określenia dotyczą zbiorów m.in. Ernesta Tytusa Bandrowskiego (1853-1920) - profesora Akademii Techniczno-Przemysłowej i Uniwersytetu Jagiellońskiego; Kazimierza Bartoszewicza (1852-1930) - krytyka literackiego, księgarza; Stanisława Wladysława Bursy (1865-1947) - kompozytora i pedagoga; Jarosława Dolińskiego (1882-1971) - chemika z krakowskiej Gazowni 
Miejskiej, numizmatyka; Stanisława Estreichera (1869-1939) - profesora i rektora Uniw. Jag.; Kazimierza Hałacińskiego (1878-1930) - bibliofila; Antoniego Zygmunta Helcla (1808-1870) - prof. Uniw. Jag., wydawcy, polityka; Tadeusza Jurystowskiego (1873-1930) - bibliofila, księgarza; Henryka Kunzeka (1871-1928) - profesora Akademii Sztuk Pięknych, lekarza $i$ in.

2. Inteligenci i ziemianie jako posiadacze księgozbiorów. Rozmiary zbiorów

Według Ireny Homoli w 1880 r. odsetek osób należących do inteligencji wynosił w Krakowie 15\% (w 1910 r. - 16\%) wszystkich pracujących, zaś we Lwowie $13 \%$ (w 1910 r. 17\%). ${ }^{14} \mathrm{~W}$ liczbach bezwzględnych we Lwowie mieszkało w 1880 r. ok. 4300 osób ( w tym 614 księży, zakonników i zakonnic), zaś w Krakowie 2500 , w tym aż 953 osoby duchowne. ${ }^{15}$ A tak pisze ona o zainteresowaniach i stosunkach panujących w inteligencji krakowskiej (hipotetycznie można to odnieść do środowiska lwowskiego): „Pracowników umyslowych w ramach poszczególnych grup zawodowych więcej dzielilo niz zblizalo. Inne byly interesy adwokata niz nauczyciela szkoly ludowej, radcy miejskiego niz kandydata aptecznego, lekarza niz artysty. (jórne warstwy rozmaitych grup laczyly zainteresowania: teatrem, sztukq. literaturq. (bossi nie mieli casu na czytanie i funduszy na rozrywki kulturalne, dlatego tez ich poziom umyslowy byl na ogól niski." "W 'W 'wietle tego stwierdzenia zrozumiały staje się fakt, że tylko niewielki procent inteligencji mógł sobie pozwolić na gromadzenie zbiorów domowych i na własny użytek. Byli to przeważnie profesorowie uczelni, niektórzy nauczyciele, wydawcy, bibliotekarze, duchowni. Wiazzało się to $\mathrm{z}$ ich przekonaniem o konieczności solidnej pracy wspartej na wyższym wykształceniu, na dobrach cywilizacji europejskiej i kultury narodowej, tj. głównie na książkach.

Nieco inaczej kształtowały się motywacje gromadzenia zbiorów u ziemian. Przede wszystkim chęć mecenasowania leżała u podłoża praktyki tworzenia księgozbiorów.

Pod względem liczebności zbiory te można podzielić na następujące grupy:

1. $25000-40000$ woluminów,

2. $15000-24999$ wol.,

3. $8000-14999$ wol.,

4. 5000 - 7999 wol., 
5. $3000-4999$ wol.,

6. $1000-2999$ wol.,

7. mniej niż 1000 wol.,

8. o nieznanej wielkości (Tabela 1).

Do najzasobniejszych zbiorów należał księgozbiór Władysława Czartoryskiego (1828-1894) - ziemianina, polityka, emigranta, liczący w chwili śmierci właściciela 100 tys. tomów. Był pod tym względem wyjatkowy, gdyż inne były o wiele mniejsze. Aleksander Oskar Franciszek Poniński (1856-1910) - ziemianin, polityk i poseł do Rady Państwa w Wiedniu miał 40 tysięcy tomów w swoim majątku rodzinnym Horyńcu (Lwowskie). Jan Smetański (1881-1959) - nauczyciel, członek Towarzystwa Miłośników Książki we Lwowie także posiadał 40 tysięcy tomów. Po 30 tysięcy woluminów liczyły zbiory Stanisława Starży Wronowskiego (1773-1839) - ziemianina, członka Stanów Galicyjskich, radcy sądów szlacheckich we Lwowie, Adriana Baranieckiego (1828-1891) - lekarza, działacza społecznego, organizatora Muzeum TechnicznoPrzemysłowego w Krakowie, Wyższych Kursów dla Kobiet, Jana Zdzisława Tarnowskiego (1862-1937) - ziemianina, polityka, także Juliusza Tarnowskiego (1901-1940), którego księgozbiór w 1932 roku wynosił 55 tysięcy woluminów. Włodzimierz Dzieduszycki (1825-1899) - ziemianin, przyrodnik i etnograf odziedziczył po ojcu - Józefie Kalasantym duży księgozbiór, także sam go pomnażał tak, że w $1861 \mathrm{r}$. liczył on 14500 tomów, a w 1875 około 20 tysięcy, zaś w 1925 roku aż 50 tysięcy. Zasobne były zbiory Jana Gwalberta Pawlikowskiego (1860-1939) - pisarza, publicysty, ekonomisty, profesora nauk społecznych w Akademii Rolniczej w Dublanach, też na Wydziale Rolnym Uniwersytetu Jagiellońskiego, odziedziczone po ojcu, Mieczysławie Gwalbercie, wynoszące w momencie przekazywania Bibliotece Zakładu Narodowego im. Ossolińskich (1921) 21503 dzieł w 26000 tomach. 
Tabela 1

Liczby księgozbiorów domowych według wielkości.

\begin{tabular}{|c|c|r|}
\hline $\begin{array}{c}\text { Grupy księgozbiorów } \\
\text { według liczebności } \\
\text { tomów }\end{array}$ & Liczby księgozbiorów & $\begin{array}{r}\text { całości księgozbio- } \\
\text { rów }\end{array}$ \\
\hline $\begin{array}{l}25000-40000 \text { i wię- } \\
\text { cej }\end{array}$ & 12 & 5,4 \\
\hline $15000-24999$ & 16 & 7,2 \\
\hline $8000-14999$ & 22 & 9,9 \\
\hline $5000-7999$ & 22 & 9,9 \\
\hline $3000-4999$ & 13 & 5,8 \\
\hline $1000-2999$ & 32 & 14,3 \\
\hline mniej niż 1000 tomów & 15 & 6,7 \\
\hline o nieznanej liczebności & 91 & 40,8 \\
\hline razem & 223 & 100,0 \\
\hline
\end{tabular}

Powyższa tabela obrazuje wielkość księgozbiorów domowych. Wynika z niej, że w oparciu o posiadane materiały badawcze jest niemożliwe stwierdzenie o stanie liczbowym aż 40,8\% tych księgozbiorów. $21 \%$ zbiorów liczy po mniej niż trzy tysiące i tysiąc tomów. Po ok. $10 \%$ przypada osobno na grupy zbiorów o wielkościach $8000-14999$ i 5000 7999 tomów.

Księgozbiory mieszczące się w przedziale 15000 - 24999 zajmują $7,2 \%$ liczby zbiorów. Najmniejszy procent przypada na kolekcje znajdujące się w przedziale 25000 - 40000 i więcej tomów, mianowicie 5,4\% wszystkich zbiorów. 
Tabela 2

Liczby tomów przypadających na poszczególne grupy księgozbiorów.

\begin{tabular}{|l|r|r|}
\hline $\begin{array}{c}\text { Grupy księgozbiorów } \\
\text { według liczebności } \\
\text { tomów }\end{array}$ & Liczby tomów & \% całości tomów \\
\hline $\begin{array}{l}25000-40000 \text { i wię- } \\
\text { cej }\end{array}$ & 546897 & 43,3 \\
\hline $15000-24999$ & 266902 & 21,1 \\
\hline $8000-14999$ & 216043 & 17,1 \\
\hline $5000-7999$ & 117915 & 9,3 \\
\hline $3000-4999$ & 48422 & 3,8 \\
\hline $1000-2999$ & 56528 & 4,5 \\
\hline mniej niż 1 000 tomów & 10984 & 0,9 \\
\hline o nieznanej liczebności & & - \\
\hline razem & 1263691 & 100,0 \\
\hline
\end{tabular}

Całkiem odwrotnie ma się rzecz, gdy będzie się rozpatrywać problem liczby tomów przypadających na poszczególne grupy księgozbiorów według liczebności (Tabela 2). Okazuje się, że na pierwszą grupę zbiorów przypada $43,3 \%$ wszystkich tomów, na drugą $21,1 \%$, na trzecią $17,1 \%$ czyli w sumie $81,5 \%$. Grubo ponad jeden milion tomów liczą księgozbiory, o których wiadomo, ile obejmują. Gdyby ponadto wzięto tu pod uwage księgozbiory o nieznanej liczebności, byłoby tomów o wiele więcej. Jest to więc liczba w tamtych czasach ogromna. Przechowywane i kompletowane całymi latami, nawet dziesiątkami lat, tworzyły dobra kulturalne o dużych rozmiarach.

\section{Podział formalny księgozbiorów}

Znaczną część stanowiły starodruki. Inkunabuły znalazły się najliczniej w zbiorach Władysława Czartoryskiego, Jerzego Henryka Lubomirskiego, Maksymiliana Marszałkowicza, Ignacego Paczkowskiego, Aleksandra Ponińskiego, Stanisława Starży Wronowskiego i Juliusza Tarnowskiego - głównie ziemian. Większość w księgozbiorach domowych stanowiły jednak druki XIX i XX-wieczne.

Gromadzono $z$ upodobaniem ryciny i wydawnictwa albumowc. zwłaszcza rękopisy. Szczególnie wyraźnie to widać, gdy śledzi się księgozbiory Wiktora Baworowskiego, Jerzego Borkowskiego, Czartoryskich 
i Tarnowskich. W zbiorach tych ostatnio przechowywany był rękopis Pana Tadeusza zanim trafił do Biblioteki Zakładu Narodowego im. Ossolińskich we Lwowie, potem we Wrocławiu.

Nie brakowało czasopism w księgozbiorach domowych, szczególnie Stanisława Bandeniego, Czartoryskich, Lubomirskich, Maksymiliana Marszałkowicza (komplety czasopism polskich), Jerzego Moszyńskiego, Edwarda Rastawieckiego i Tomasza Zielińskigo.

Pokaźna pozycję $w$ zbiorach domowych stanowiły regionalia (leopolitana, cracoviana itp.) w postaci druków, map, planów, rycin, sztychów, portretów i obrazów. Widoczne to jest głównie u takich ich właścicieli, jak: Władysław Walenty Fedorowicz, Józef Edward Friedlein, Ludwik Łętowski (bogaty zbiór druków unglerowskich i hallerowskich), Mieczysław Opałek, Pawlikowscy $\mathrm{i}$ in.

Zbiory domowe były różnojęzyczne. Obejmowały pozycje w językach niemieckim, francuskim, angielskim, rosyjskim, nie mówiąc o polskim, łacinie $\mathrm{i}$ grece. Można znaleźć jeszcze nieliczne publikacje w językach węgierskim, czeskim, włoskim $i$ in. Świadczyć to mogło nie tylko o różnorodności wielojęzycznej księgozbioru, lecz także o żywych stosunkach kulturowych w tamtych czasach. Tym bardziej to jest wyraziste gdy przyjrzymy się geografii miejsc, gdzie były wydane pozycje znajdujące się w księgozbiorach domowych. Były reprezentowane wszystkic ważniejsze ośrodki wydawnicze ówczesnej Europy. Najliczniej jednakże Lwów, Kraków i Warszawa. Książki wydawane w różnych miejscach Europy i Polski, a gromadzone przez inteligencję i ziemian, stawały się więc czynnikiem integrującym mimo dzielących granic zaborów, także pomostem do innych krajów.

W księgozbiorach domowych reprezentowana była bardzo licznie literatura piękna, poczynając od antycznej, a kończąc na współczesnej polskiej, niemieckiej, francuskiej, angielskiej, włoskiej, rosyjskiej $\mathrm{i}$ in. Józef Dzierzkowski "Dobek" zgromadził bizantynica $i$ armenica w szerokim wyborze, Antoni Stadnicki - slavica. Większość w zbiorach domowych stanowila literatura niebeletrystyczna. Adrian Baraniecki zgromadził cenny księgozbiór specjalistyczny z zakresu techniki, Józef Edward Friedlein, Adam Mieleszko-Maliszkiewicz, Józef Münnich i Jan Smetanski - przyrodoznawstwa, Marian Gawalewicz - dramaturgii, Aleksander Poniński - balneologii, Józef Szujski - historii, Władysław Wszelaczyński - muzyki.

Biorąc pod uwage wszystkie kwestie, jakie nasuwają się w zwiąku $z$ podziałem księgozbiorów domowych ze względu na formę, okazuje się 
s aż nadto wyraźnie, że cechują się one różnorodnością pod względem

0 rodzajów dokumentów, jakie zawieraja, także językowym, miejsca wydania, chronologii.

\section{Charakterystyka rzeczowa księgozbiorów}

Przyjęto tu następujący podział dziedzin wiedzy i według niego będzie się charakteryzować księgozbiory:

1. dział ogólny,

2. nauki humanistyczne i społeczne,

3. nauki matematyczno-przyrodnicze i techniczne,

4. nauki o Ziemi i

5. nauki o gospodarstwie wiejskim.

Jeżeli chodzi o dział ogólny, zwykle ma się na uwadze, jak wiadomo, encyklopedie, słowniki, katalogi, bibliografie, roczniki czasopism, kalendarze, rękopisy, inkunabuły, wydawnictwa zbiorowe różnej treści. Szczególnie cenne $\mathrm{z}$ tego działu zbiory posiadał Wiktor Baworowski. Miał on aż 1080 rękopisów, w tym dwa iluminowane z XII w., Kronike W.Kadłubka i bogaty zbiór czasopism emigracyjnych. Niezwykle liczny zbiór rękopisów, bo aż 1972, miał Adam Jerzy Czartoryski, Władysław Czartoryski zgromadził 2400 inkunabułów i druków polskich z XVI w., Zygmunt Stanisław Dragowski posiadał liczne dawne czasopisma. Józef Dzierzkowski „Dobek” szczycił się kodeksami rękopiśmiennymi XVXVIII w., zaś Stanisław Filip Krzyżanowski - aż 5 tys. manuskryptów, Lubomirscy zgromadzili liczne czasopisma (kilka tysięcy), także Maksymilian Marszałkowicz posiadał komplety czasopism polskich. To samo można powiedzieć o Jerzym Moszyńskicm.

Encyklopedie i słowniki można spotkać w dużym wyborze w zbiorach Józefa Kalasantego Szaniawskiego, także Czartoryskich, Lubomirskich, Pawlikowskiech, Potockich, Sanguszków, Tarnowskich, Stanisława Starży Wronowskiego i Franciszka Jaworskiego.

Liczne kalendarze posiadali Adam Mieleszko-Maliszkiewicz, zaś druki bibliofilskie w szerokim wyborze - Jarosław Dolinski i Mieczysław Opałek.

Bibliografie można znaleźć w zbiorach Piotra Moszyńskiego.

Nauki humanistyczne i społeczne są najliczniej reprezentowane w księgozbiorach domowych. Oprócz literatury pięknej, o której pisano 
wyżej, szczególnie historia jest tą dziedzina, której dotyczy najwięcej pozycji.

Oswald Marian Balzer i Antoni Helcel posiadali duże zbiory z zakresu historii prawa polskiego. Jerzy Samuel Bandtkie i Ludwik Bernacki zgromadzili dużo z historii literatury, a Eugeniusz Barewicz, Stanisław Bursa, Jarosław Doliński i Julian Kołaczkowski - historii sztuki, Józef Dzieduszycki miał pozycje w dużym wyborze dotyczące historii Polski. Podobnież Wiktor Baworowski, Czartoryscy, Józef Dzierzkowski „Dobek”, Franciszek Jaworski, Michał Konarski, Józef Ignacy Kraszewski, Ludwik Łętowski (kompletne piśmiennictwo historyczne z czasów Księstwa Warszawskiego), Adam Mieleszko-Maliszkiewicz, Józef Szujski $\mathrm{i}$ in.

Dość licznie prezentowały się zbiory dotyczące prawa. Szczególnie to widać w księgozbiorach Józefa Friedleina, Antoniego Helcla, Ignacego Łosia, Maksymiliana Marszałowskiego, Jana Kantego Podoleckiego, Kazimierza Stadnickiego, Marcina Strzelbickiego i Józefa Kalasantego Szaniawskiego.

Językoznawstwo reprezentowane było licznymi zbiorami u Jerzego Samuela Bandtkiego, Łukasza Dąbskiego (retoryka) i Józefa Szujskiego.

Problemów religii, teologii i religioznawstwa dotyczyły zbiory zgromadzone licznie przez Witolda Czartoryskiego, Helenę Dąbczańską (duży zbiór jezuiticów), Jana Kasprowicza, Jana Ławrowskiego (głównie teologia grecko-katolicka), Ignacego Łosia, Jerzego Moszyńskiego, Jana Kantego Podoleckiego, Romana Sanguszki, Wacława Sierakowskiego, Jerzego Szembeka i Józefa Szujskiego.

Filozofia była reprezentowana dość licznie w zbiorach Wiktora Baworowskiego, Czartoryskich, Józefa Dzierzkowskiego „Dobka”, Mariana Gawalewicza, Jana Kasprowicza, Adama Mieleszki-Maliszkiewicza, Jana Podoleckiego, Antoniego Stadnickiego, Józefa Kalasantego Szaniawskiego, Ludwika Zielińskiego.

Także oświacie i szkolnictwu poświęcono nieco miejsca w niektórych księgozbiorach domowych. Dotyczy to zbiorów głównie Mieczysława Opałka, Józefa Szaniawskiego, Józefa Szujskiego i Czartoryskich.

W mniejszym zakresie $w$ stosunku do nauk humanistycznych i społecznych reprezentowane były w księgozbiorach domowych nauki matematyczno-przyrodnicze i techniczne. Książki dotyczące przyrody, medycyny można spotkać w zbiorach Eugeniusza Barewicza, Stanisława Borkowskiego, Macieja Brodowicza, Włodzimierza Dzieduszyckiego, Józefa Dzierzkowskiego „Dobka”, Józefa Friedleina, Adama Mieleszki- 
Maliszkiewicza, Józefa Münnicha, Jana Smetańskiego, Jana Smoniewskiego i Karola Ziembickiego.

Dzieła z zakresu matematyki, geometrii, fizyki, techniki i geografii, znajdowały także pewne miejsce w zbiorach domowych. Szczególnie to uwidoczniło się w przypadku Adriana Baranieckiego, Tytusa Chałubińskiego (carpatica), Witolda Czartoryskiego (liczny zbiór dotyczący nauk ścisłych), Daniela (papiernictwo) i Józefa Friedleinów (geologia), Ignacego Polkowskiego (zbiór kopernikanów), Klementyny Sanguszkowej i Sebastiana Sierakowskiego.

W księgozbiorach domowych znajdowały się liczne pozycje odnoszące się do nauki o gospodarstwie wiejskim. Nie brakowało też pozycji o łowiectwie. Dotyczy to zbiorów Józefa Dzierzkowskiego „Dobka”, Jana Smoniewskiego i Karola Ziembickiego.

Różnorodność tematyczna zbiorów domowych jest więc namacalna. Zapewne była podyktowana różnorodnymi upodobaniami i zainteresowaniami czytelniczymi ich właścicieli. Szczególne miejsce w nich znajdowały książki dotyczące historii i literatury polskiej, jako że wiedza o kraju interesowała najbardziej, a dla niektórych (np. J.Szujski) - stanowiły warsztat pracy naukowej.

\section{Losy księgozbiorów domowych}

Najczęściej właściciele ofiarowali swe zbiory bibliotekom i różnym instytucjom naukowym. Biblioteka Jagiellońska otrzymała od Jerzego Samuela Bandtkiego, Adriana Baranieckiego (w części), Macieja Józefa Brodowicza, Stanisława Bursy, Władysława Dąbskiego, Józefy Gostkowskiej, Antoniego Helcla (w części), Józefa Ignacego Kraszewskiego (książki), Stanisława Filipa Krzyżanowskiego (rękopisy), Andrzeja Lubomirskiego (w części), Adama Mieleszki-Maliszkiewicza (w części), Ignacego Żegoty Paulego (rękopisy i mapy), Klementyny Sanguszkowej (stare druki i rękopisy), Jana Schindlera. Sebastiana Sierakowskiego i Jana Zdzisława Tarnowskiego (w części).

Niemniej obficie wpływały zbiory domowe do Biblioteki Zakładu Narodowego im. Ossolińskich. Stanisław Badeni ofiarował jej swój cenny księgozbiór, podobnie uczynił Oswald Balzer. Znalazły się w niej zbiory Wiktora Baworowskicgo, I udwika Bcmackicgo, Udalrya Mikołaja Cieńskiego (w części), Aleksandra (rolowskiego (ręliopisy), Whodzimierza Dzieduszyckiego (w ezęści), Józela Dzierzkowskiego ..Dobka" 
(cimelia), Lubomirskich (w części), Mieczysława Opałka (w części), Pawlikowskich (w części), Aleksandra Stadnickiego (rękopisy), Stanisława Starży Wronowskiego (w części) i Juliusza Tarnowskiego (w części).

Biblioteka Narodowa w Warszawie wzbogaciła się zbiorami domowymi: Aleksandra Czołowskiego (w części), Antoniego Helcla (w części), Stanisława Filipa Krzyżanowskiego (3 rękopisy), Ludwika Morstina, Ignacego Żegoty Paulego (w części) i Alcksandra Ponińskiego (Biblioteka Horyniecka XX. Ponińskich).

Również Biblioteka PAN w Krakowie otrzymała sporo darów ze strony właścicieli księgozbiorów domowych. Trafiły do niej zbiory Adriana Baranieckiego (w części) - najpierw do Biblioteki AU, Antoniego Helcla (papiery osobiste $\mathrm{i}$ inne), Michała Konarskiego, Józefa Ignacego Kraszewskiego (niektóre książki), Stanisława Filipa Krzyżanowskiego (w części), Maksymiliana Marszałkowicza (część wraz z katalogiem), Jerzego Moszyńskiego (kolekcja rycin), Józefa Münnicha (w części) i Karola Witolda Ziembickiego.

Inne biblioteki i instytucje otrzymały w porównaniu $\mathrm{z}$ wymienionymi wyżej książnicami o wiele mniej darów od właścicieli zbiorów domowych. Do Naukowego Instytutu Katolickiego w Krakowie wpłynęła część księgozbioru Stanisława Badeniego, która obecnie znajduje się w tamtejszej Miejskiej Bibliotece Publicznej. Gmina m. Lwowa obdarowana została księgozbiorem Eugeniusza Barewicza; stał się on podwaliną Biblioteki Królewskiego Stołecznego m. Lwowa (Biblioteki Miejskiej). Do niej trafiły także zbiory Zygmunta Stanisława Dragowskiego (w pokaźnej części), Mariana Gawalewicza i Władysława Lozińskiego (w częśsi).

Biblioteka Uniwersytecka we Lwowie otrzymała zbiory Stanisława Borkowskiego, Witolda Kazimierza Czartoryskiego (w części), Michała Formaniosza i Władysława Łozińskiego (w części).

Biblioteka Akademii Muzycznej w Krakowie zakupiła część księgozbioru Stanisława Władysława Bursy. Biblioteki Muzeum Tatrzańskiego w Zakopanem i Towarzystwa Oświaty Ludowej w Nowym Targu oraz Muzeum Karpackie w Popradzie otrzymały zbiory Tytusa Chałubińskiego.

Dział marynarski zbiorów Witolda Kazimierza Czartoryskiego przypadł Państwowej Szkole Głównej Marynarki Polskiej.

Archiwalia Aleksandra Czołowskiego znalazły się w Archiwum Głównym Akt Dawnych. Zbiory Heleny Dąbczańskiej przekazane zostały 
Muzeum Narodowemu na Wawelu, Bibliotece Muzeum Przemysłowego w Krakowie i innym muzeom.

Macierz Szkolna w Cieszynie otrzymała część księgozbioru Józefa Ignacego Kraszewskiego. Część przyrodnicza zbiorów Stefana Andrzeja Lubomirskiego została przeznaczona Państwowemu Muzeum Przyrodniczemu w Warszawie. Jan Ławrowski oddał księgozbiór przemyskiej kapitule greckokatolickiej, zaś Ludwik Łętowski - kilkanaście foliałów Bibliotece OO. Dominikanów w Krakowie.

Zbiory Ignacego Łosia trafiły do Biblioteki Publicznej w Warszawie. Katolicki Uniwersytet w Lublinie otrzymał księgozbiór Jerzego Moszyńskiego.

Niektóre partie zbiorów Mieczysława Opałka przeszły na własność Bibliotki Uniw. we Wrocławiu, Warszawie i KUL-u.

Rękopisy i inkunabuły Ignacego Polkowskiego zostały przekazane testamentem Bibliotece Seminarium Duchownego w Warszawie, zaś jego kopernikana znalazły się w Muzeum Kopernika w Rzymie.

Edward Rastawiecki ofiarował część zbiorów Katedrze Archeologii Uniw. Jagiellońskiego.

Księgozbiór Antoniego Ryszarda został przekazany do Biblioteki Czapskich w Krakowie. Klementyny Sanguszkowej zostały rozdzielone między Bibliotekę Jagiellońską (stare druki i rękopisy), o czym pisano wyżej, Bibliotekę Uniwersytecką we Wrocławiu (książki polskie nowsze) i Archiwum Państwowe w Krakowie (archiwum rodzinne Sanguszków).

Wincenty Smagłowski "Nowina" ofiarował zbiory Bibliotece Miejskiej w Stanisławowie. Część księgozbioru Jana Smetańskiego została zakupiona przez Instytut Zoologii PAN w Warszawie i Bibliotekę Śląska, Towarzystwo Naukowe Krakowskie otrzymało zbiory Jana Wincentego Smonikowskiego, Biblioteka Uniw. w Warszawie (za pośrednictwem Biblioteki Sądu Apelacyjnego) - Anzelma Speisera.

Księgozbiór Józefa Kalasantego Szaniawskiego został rozdzielony między Bibliotekę Warszawskiego Muzeum Przyjemności Użytecznej Zabawy (w formie tymczasowego depozytu), Jezuicką Bibliotekę Prowincji Małopolskiej w Krakowie i Bibliotekę Uniw. w Warszawie. Zbiory Jerzego Józefa Szembeka znalazły się w Bibliotece Śląskiej. Józef Szujski ofiarował Nowemu Sączowi (obecnie znajdują się w tamtejszej Woj. Bibliotece Publicznej).

Biblioteka Miejska w Gdańsku otrzymała część zbiorów Juliusza Tarnowskiego, zaś rękopisy przypadły Archiwum Głównemu Akł Dawnych w Warszawie i Archiwum w Krakowie. Dzieła sztuki i stare druki 
Adama Wolańskiego ofiarowane zostały Muzeum Narodowemu w Krakowie.

Część dzieł o muzyce, pozostających we władaniu Władysława Wszelaczyńskiego, trafiła do Biblioteki Towarzystwa Muzycznego we Lwowie, a zbiory Romana Zawilińskiego - do Biblioteki Publicznej w Tarnowie i Biblioteki Uniw. w Poznaniu.

Większość księgozbioru Ludwika Zielińskiego znalazła się w Bibliotece Archiwum Miejskiego we Lwowie, zaś Tomasza Zielińskiego (w części) w Bibliotece Czartoryskich w Krakowie.

$\mathrm{Z}$ tego krótkiego przeglądu losów zbiorów domowych inteligencji i ziemian wynika, że większość trafiła do bibliotek naukowych. Niewielka tylko ich część znalazła się w innych bibliotekach, ponadto $\mathrm{w}$ archiwach i muzeach. Niestety, niektóre uległy rozporoszeniu, lub zniszczeniu. Czesściowo zostały zniszczone zbiory Udalryka Mikołaja Cieńskiego, Wincentego Piątkowskiego (w całości), Aleksandra Ponińskiego, Romana Damiana Sanguszki, Jerzego i Józefa Szembeków. Rozprzedano niektóre pozycje ze zbiorów Józefa Dzierzkowskiego „Dobka”, Juliana Kołaczkowskiego i Ludwika Zielińskiego. Księgozbiór Władysława Walentego Fedorowicza uległ spaleniu. Dotyczy to także zbiorów Daniela Edwarda Friedleina, Ludwika Morstina (w części) i Jana Zdzisława Tarnowskiego, zaś Franciszka Jaworskiego, Wacława Sierakowskiego i Stanisława Starży Wronowskiego (w części) zostały rozporoszone.

\section{Wykorzystanie zbiorów}

Praca intelektualna, jaka jest udziałem przede wszystkim inteligencji wykonującej zawody nauczyciela, inżyniera, adwokata, sędziego itp., wymaga z konieczności korzystania z wszelkiego rodzaju pomocy naukowych, jak ksiażki, czasopisma, mapy, rękopisy itp. Dlatego też księgozbiór domowy bywa zwykle produktem nie jej jako określonej warstwy, czy grupy społecznej, ale zawodu, jaki pełni, wynikiem profesjonalnej potrzeby. Natomiast w przypadku ziemiaństwa mamy do czynienia głównie $z$ misją mecenasowania kulturze. Książki, czasopisma i inne dokumenty gromadzone były ze względu głównie na nie same. Stąd też księgozbiory domowy tej grupy społecznej są bardziej ogólne, podczas gdy inteligencji - specjalne. Ale obie te cechy charakterystyczne, zdawałoby jaskrawo przeciwstawne $\mathrm{w}$ budowaniu tych zbiorów przez te warstwy społeczne, zachowuja rys wspólny: przekonanie ich właścicieli, 
że ich gromadzenie jest konieczne ze względu na dobro kultury narodowej, a korzystanie $\mathrm{z}$ nich jest wymogiem statusu człowieka aktywnego nie tylko zawodowo, ale społecznie, ekonomicznie itp.

Niestety, problem wykorzystania księgozbiorów domowych nie jest przedmiotem powszechnego zainteresowania badaczy. Ciagle pozostaje niezbadany, ale i nie badany. O ile struktura zbiorów, a nawet ich proweniencja $i$ los znajduja odbicie w pracach naukowych, to w odniesieniu do ich spożytkowania jest głucho. W tej sytuacji konieczne jest sięganie do źródeł pośrednich - takich, jak zapiski w katalogach i inwentarzach księgozbiorów, wspomnienia i pamiętniki, listy prenumeratorów zawarte w Zlotej księdze szlachty polskiej i słowniku 1787-1914 Bogumiła Lindego, aby coś konkretnego powiedzieć, jak zbiory te były wykorzystywane i w jakim charakterze.

W świetle tych źródeł widoczne były różne formy wykorzystywania księgozbiorów domowych. Warto zwrócić uwagę na ich parę - na te, które były najpowszechniejsze. Są to: po pierwsze, forma bezpośredniego wykorzystywania poszczególnych pozycji, czy tylko części zbiorów głównie przez ich właścicieli, przyjaciół, znajomych i krewnych; po wtóre, traktowanie księgozbiorów domowych jako placówek naukowych i instytucji wydawniczych; po trzecie, ich udostępnienie publiczności; wreszcie po czwarte, przekazanie w formie daru lub sprzedanie bibliotekom naukowym lub publicznym do użytku powszechnego. Wszystkie te formy narzuciły pewne ramy rozwiazań praktycznych funkcjonowaniu księgozbiorów domowych i zdeterminowały w znacznym stopniu ich dalszy los.

Sposób, w jaki dochodzila do głosu pierwsza forma wykorzystania księgozbiorów domowych, każe przypuszczać, że była ona powszechna. Przede wszystkim sam właściciel był stałym czytelnikiem zbiorów i to ze względu na potrzeby pracy naukowej.

$\mathrm{Na}$ stronach 4 i 6 Katalogu biblioteki polskiej Józefa Szujskiego z 1876 r. umieszczono nazwiska osób i tytuły książek pożyczonych przez niego (,Na pożyczkach”):

U Łuszczkiewicza: Monumenta Bielowskiego tom 2gi (przekreślono widocznie zostały zwrócone),

U Tarnowskiego: Dembińskiego: Domina, Palatti Libertas, Kubali Orzechowski $\mathrm{i}$ inne razem oprawione,

U Radzimińskiego: Długosz polski t. 3, Letopisy tom jeden, Grabowski: Źródlo dziejów polskich, Paprocki, Herbar=, 
U Smolki: Bartoszewicz: Hist. (literatury polskiej), Lelewel: Polska w. średnich $\mathrm{t}$. jeden, Codex epistolaris (przekreślony),

U Zakrzewskiego: Karwowski: Wojna infl., Wolff Tartaren,

U Mostowskiego: Turgieniew $2 \mathrm{t}$,

U Polkowskiego: Rel dei ambasciatori Veniti (przekreślone),

U Nowakowskiego: Le faus Demetrius,

U Bobrzyńskiego: Dyaryusz Kojałowicza (przekreślone),

U G.Ch. : Sejm czteroletni Kalinki (przekreślone),

Mycielski: Wasilewski 1. 4, Studya Liskego, Żółkiewski, Lubomirski,

Dąbski: Caro, Gesch. Polens III (przekreślone),

U Smolki: Hummerburgstall.

Są to głównie luminarze nauki polskiej w XIX w. i jak świadczą zapiski - użytkownicy książek o tematyce historycznej, należących do księgozbioru J.Szujskiego.

Notatki sporządzone na przedniej okleinie spisu Jana Kantego Podoleckiego ilustruja że jego księgozbiór był wykorzystywany przez różne osoby. Są to następujące zapiski: „W. Michal (rroblewski 6 lipca 813: Pamiętnik L. - 2 tom. Rolnictwo prema - 1, Naruszewicz, poezie - 1, Plutarcha - I"; „Pozyczono Okólskiemu Satyry Corczyczewskiego - 2, Sybilla Woronicza - 1, Ja będę: Święckiego - 2, Wega-1, taski - I", a na ostatniej: „Pozyciam dzielo pod tytulem. Josephi. Judei praeclara opera. Parisii 1519 in folio. Rzepedź 11 Maja 820. Niewyraźny podpis", "Pożyczam 4 tomy Mataszewskiego: 2 tomy i 2 tomy Bossueta i Wolterarazem ksiazek - 29 lipca 822. Nieczylelny podpis”; „W. Tadeuszowi Urbańskiemu Felińskiemu tom. I, Templariusze - 1, Katylina - I".

Działalność naukowa i wydawnicza bibliotek głównie wielkoziemiańskich - to następna forma wykorzystania zbiorów domowych. A oto niektóre charakterystyczne przykłady.

Wiktor Baworowski zamierzał w latach pięćdziesiątych XIX wieku utworzyć fundację biblioteczną w oparciu o swój majątek w okolicach Tarnopola i ulokowawszy bibliotekę we Lwowie w latach 1856-61, zatrudnił w niej Henryka Schmitta - historyka, publicystę i bibliotekarza. Ten w $1861 \mathrm{r}$. ułożył regulamin dla mającej powstać fundacji bibliotecznej i zaczałł pracować nad kartkowym katalogiem rycin.

W latach 1875-76 ulokowano w Krakowie część zbiorów ziemiańskich Władysława Czartoryskiego, następnie przeniesiono tam także zbiory kórnickie Czartoryskich. W $1876 \mathrm{r}$. zostały udostępnione społeczeństwu pod nazwą Zbiory XX. Czartoryskich, a następnie Muzeum XX. Czartoryskich w Krakowie. Do 1880 r. prawie cały ksiegozbiór 
znalazł się w ofiarowanym przez zarząd miasta dawnym arsenale. Od 1876 r. kustoszem zbiorów został Leon Jarosław Bentkowski, który od jesieni 1871 r. sprawował opiekę nad biblioteką Władysława Czartoryskiego, znajdującą się w Hotelu Lambert. Jako kustosz Muzeum i Biblioteki Czartoryskich w Krakowie, sporządził pierwszy kompletny katalog zbiorów muzealnych i graficznych, opracował też katalog dyplomów pergaminowych.

Po śmierci Władysława Czartoryskiego Muzeum i Bibliotekę Czartoryskich przejął jego syn Adam Ludwik (1872-1937), który utworzył ordynacje sieniawską w celu zagwarantowania instytucji podstaw materialnych do funkcjonowania. Za jego czasów kierowali nią: Marian Sokołowski (przez okres 1884-1911), Stanisława Smolka (w latach 19121915) i in. Kierownikiem wyodrębnionej w 1889 r. Biblioteki byli: Bolesław Biskupski (w latach 1889-1918), który uzupełnił jej katalog. Jest autorem pracy pt. Rezultat porównania egzemplarza "Joannis de Turrecremata Explanatio in Psalterium (rucis" z Biblioteki ks. ('zartoryskich z opisem egzemplarza Biblioteki Ordynacji Zamojskiej w Warszawie, zamieszczonej w Przegladzie Bibliograficzno-Archeologicznym w roku 1882. Pozostawił w rękopisie bibliografię zawartości krakowskiego dziennika (zas za lata 1848-1892, także notaty z opisami druków i rozwiazaniami pseudonimów.

Gdy Włodzimierz Dzieduszycki odziedziczył bibliotekę po ojcu Józefie Kalasantym w Poturzycy, przeniósł ją do Lwowa, powierzył w 1855 r. opiekę i opracowanie zbiorów Józefowi Łozińskiemu, który pracował w niej aż do śmierci (1897 r.). Sporządził jej katalog kartkowy, wyłączył rękopisy i ułożył je chronologicznie. Jemu Biblioteka zawdzięczała piękne działy aldów, stephanów i elzewirów nabytych drogą kupna lub wymiany.

Gwalbert Józef Pawlikowski już w latach dzwudziestych XIX wieku rozpoczał gromadzić książki i sztychy najpierw w Wiedniu, potem przeniósł do swego majatku w Medyce k. Przemyśla. W latach 1834-39 Kajetan Wincenty Kielisinski porządkował i opracowywał zbiory graficzne. Po nim Stanisław Przyłęcki przez cztery lata opracowywał księgozbiór, a od $1850 \mathrm{r}$. - już po przeniesieniu w 1849 r. biblioteki do Lwowa - bibliotekarzem jej był Henryk Schmitt aż do śmierci (1883 r.). Po nim Ludwik Kubala (aż do śmierci w 1918 r.).

Jeżeli chodzi o bibliotekę Romana Sanguszki w Sławucie, trzeba tu odnotować jedną z pierwszych w Polsce drukowanych tego typu publikacji: Spis rekopisoin biblioteki slawuckiej sporządzony przez J.T. Stec- 
kiego (w: „Wolyn" t. 1, Lwów 1864, s. 357-360). Nad opracowaniem księgozbioru biblioteki pracowali liczni konserwatorzy i bibliotekarze, jak Jan Krechowiecki, Władysław Szumiński, Leon Romanowski, Józef Piotrowski i in.

Bibliotekarzami u Adama Stanisława Sapiehy w jego bibliotece krasiczyńskiej byli Bolesław Mańkowski, następnie J. Łukaszewicz.

U Tarnowskich pracowali nad porządkowaniem zbiorów dzikowskich kolejno: Łukasz Gołębiowski (autor Sumariusza w archiwum Dzikowa lezacych papierów), Seweryn Biliński, który z pomocą Stanisława Jachowicza i Slebodzińskich sporzadził katalog dzieł polskich, który stanowić miał tom 1 istniejącego już Katalogu dziel cudzoziemskich oraz uzupełniał facsimiliami zdefektowane druki z XVI - XVII w. W latach 1831-34 opiekował się biblioteką Franciszek Maksymilian Sobieszczański. W 1850 r. został sporządzony Katalog biblioteki Tarnowskich w Dzikowie przepisany dla Stanistawa Przylęckiego w roku 1850. W 1908 r. ukazał się katalog Rękopisy biblioteki Tarnowskich w Dzikowie, opracowany przez Adama Chmiela ("Przewodnik Bibliograficzny” 1907-1908 i odb.), takze Dodatkowy spis rękopisów biblioteki dzikowskiej w opracowaniu Stanisława Vrtela - Wierczyńskiego (tamże i odb.). Od 1913 r. bibliotekarzem został Michał Marczak.

Następną formą wykorzystania zbiorów domowych było ich udostępnianie publiczności. Stało się tak w przypadku księgozbioru Wiktora Baworowskiego. Został on udostępniony publiczności za pośrednictwem Biblioteki Ossolineum w 1900 r. Kierowali biblioteką Józef Korzeniowski (w latach 1899-1905), Edward Naganowski (w okresie 1905-15) i in. Nie była to forma powszechna. Zbiory innych ziemian były udostępniane nielicznym badaczom, głównie były gromadzone i opracowywane.

Powszechnym zjawiskiem stało się przekazywanie zbiorów przez ich właścicieli w formie darów różnym bibliotekom naukowym, głównie Jagiellońskiej i Ossolineum. Na 102 księgozbiory tu omawiane 66 trafiło w takiej czy innej formie do różnych bibliotek. Tam opracowane i włączone do zbiorów są wykorzystywane prze szeroką publiczność czytelniczą na zasadach powszechnych. 
W podsumowaniu można stwierdzić, że:

1. książki gromadzone stawały się nie tylko symbolem statusu społecznego, lecz narzędziem uprawiania zawodu zwłaszcza dla nauczycieli uczelni, szkół, lekarzy itp.,

2. były formą aspiracji mecenasowskich - głównie dla ziemian,

3. stawały się czynnikiem integrującym bez względu na dzielące granice zaborów,

4. to pomost do Europy zachodniej i innych krajów - zwłaszcza dla polskiej inteligencji,

5. książki gromadzone $\mathrm{i}$ następnie darowane bibliotekom naukowym i publicznym to dobro kulturowe o dużym znaczeniu dla nauki i kultury narodowej, także oświaty.

Przypisy:

Z.Staniszewski: Inwentarze biblioteczne wieku XVII i XVIII w rękopisach Ossolineum. Odbitka. Wrocław 1968; W. Jabłonska: Inwentarze i katalogi biblioteczne w zbiorach rękopismiennych Biblioteki Zakładu Narodowego im. Ossolinskich, W: „Ze skarhca kultury" 1969, Z. 20, s.73-179.

2 U.Paszkiewicz: Bibliografia inwentarzy i katalogów księgozhiorów polskich i zatozonych w Polsce do 1939 roku, Warszawa 1990. Częśc 2.

${ }^{3}$ E.Chwalewik: Zhiory polskie, Warszawa 1926-27. T. 1-2; Fr.Radziszewski: Wiadomośc historyczno-statystyczna o znakomitszych bibliotekach $i$ archiwach publicznych i prywatnych, Kraków 1875

${ }^{4}$ K. Maleczyńska: Ksiqzki i biblioleki w Polsce w okresie zaborów, Wrocław 1977.

J.Szocki: Księgozbiory domowe inteligencji $i$ ziemian $w$ (ialicji $w X I X$ i na poczqtku $X X$ w. (w świetle badań), ,Biuletyn Informacyjno-Instrukcyjny Miejskiej Biblioteki Publicznej w' Krakowie" 1992, nr 3/171, s. 38-62.

"Zbiory rękopisów w bibliotekach i muzeach w Polsce. Oprac. D. Kamolowa przy współudziale K.Muszyńskiej, Warszawa 1988

${ }^{7}$ M.Pawlik: Katalog księgozhioru, rękopisów, dyplomów, rycin, map, atlasów, fotografii jako też osobistych dyplomów... pozostatych po śp. Józefie Ignacym Kraszewskim, Lurow 1888.

' J.Jarowiecki: Księgozhiór Jozzefa Ignacego Kraszewskiego, w: „K'siq̇ki, czasopisma, biblioteki Krakowa XIX i XX wieku", Kraków 1988, s. 99-137

'J Jarowiecki: Księgozbior Jozefa Ignacego Kraszewskiego - warsztatem pracy pisarza i historyka, ,Szczecinskie Prace Polonistyczne” 1991, nr 3, s. 67-92.

10 J. Szocki: Księgozbior domowy Jizefa Szujskiego w swietle sporzqdzonych jego rękq katalogów, „Biuletyn Biblioteki Jagiellonskiej”. Część 1. R. 39, 1989, s. 101-119; Część 2. R. 40, 1990, s. 33-124, tenże: Ksiqzka historyczna w księgozhiorze domowym Józefa Szujskiego (1835-1883), Roczniki Biblioteczne R. 34, 1990, z. 1-2, s. 101-113; tenże: ('zasopisma $i$ ich miejsce w księgozbiorze domowym Józefa Szujskiego (1835188.3), "Kwartalnik Historii Prosy Polskiej” 31, 1992, z. 1, s. 71-88; tenże: I.iteratura $i$ 
opracowania o tematyce antycznej w księgozbiorze domowym Jana Kantego Podoleckiego, ,Meander" 1993, nr 11-12, s. 565-572.

11 Stownik pracowników ksiazki polskiej. Pod red. Ireny Treichel, Warszawa 1972; Słownik pracowników ksiazki polskiej. Suplement. Pod red. Ireny Treichel, Warszawa 1986.

${ }^{12}$ Encyklopedia Wiedzy o Ksiquice, Wrocław 1971; Polski Slownik Bibliograficzny poszczególne tomy.

13 Bibliografia prac magisterskich, doktorskich i habilitacyjnych wykonanych w' Instytucie Bibliotekoznawstwa 1961-198-, Wrocław 1988; Bihliografia prac magisterskich wykonanych w Zakladzie Bibliotekoznawswa i Informacji Naukowej w latach 1978-1981. Oprac. Elżbieta Bławat, Sosnowiec 1982; Bibliografia prac magisterskich wykonanych w Zakladzie Bibliotekoznawstwa i Informacji Naukowej w roku 1982. Oprac. Antoni Gazda, Sosnowiec 1983; Bibliografia prac magisterskich wykonanych w Zakladzie Bibliotekoznow'stwa Wysszej S $\approx k o l y$ Pedagogicznej im. Komisji Edukacji Narodowej w Krakowie w latach 197-1999. Oprac. Marek Pieczonka. Kraków 1980; Bibliografia prac magisterskich wykonanych w' Zaktadzic Bibliotekoznawstwa i Informacji Naukowej Wyższej Szkoly Pedagogicznej im. Jana Kochanowskiego w Kielcach za lata 1979-1985. Oprac. Grazyna Gulinska, Kielce 1986; Bibliografia prac magisterskich wykonanych w Samodzielnym Zakladzie Bibliotekoznawstwa Wyzszej Szkohy Pedagogicznej im. Komisji Edukacji Narodowej za rok 1980. Oprac. Grazyna Dymańska, Marek Pieczonka, Kraków 1981; Bibliografia prac magisterskich wykonanych w Samodzielnym Zakladzie Bibliotekoznawstwa Wyzszej Szkoty Pedagogicznej im. Komisji Edukacji Naukowej za rok 1981. Oprac. Grażyna Wrona, Marek Pieczonka, Kraków 1982; Bibliografia prac magisterskich wykonanych w'Samodzielnym Zakładzic Bibliotekoznawstwa Wyzszej Szkoty Pedagogicznej im. Komisji Edukacji Naukowej za lata 1982 i 1983. Oprac. Barbara Góra. Kraków 1984; Bibliografia prac magisterskich wykonanych w Katedrze Bibliotekoznawstwa i Informacji Naukowej WSP... w Krakowie za lata 1985-1991. Oprac. Marek Glogier, Mieczysław Więcławek. Kraków 1992.

14 J.Homola: „Kwiat spoteczeństwa...” (struktura spoleczna i zarys położenia inteligencji krakowskiej w latach 1860-1914), Krakow 1984, s. 11.

is Tamże, s. 11-12.

16 Tamże, s. 381 .

17 Por. R.Czepulis-Rastenis: Wzór osobowy inteligenta polskiego w świetle wspomnień pośmiertmych (1863-1872), w: Inteligencja polska pod zaborami, Warszawa 1978, s.159-178. 


\section{Wprowadzenie \\ do wykazów właścicieli księgozbiorów domowych \\ w Galicji (1795-1914)}

Materiał został ujęty w sześciu rubrykach:

1. Nazwisko i imię właściciela;

2. Profesja, funkcja pełniona i przynależność społeczna;

3. Liczba tomów księgozbioru;

4. Tematyka zbiorów;

5. Los zbiorów;

6. Źródła informacji o księgozbiorze.

Brak danych oznaczono kreską.

\section{Wykaz}

właścicieli księgozbiorów domowych w Galicji

(od ok. 1000 i więcej tomów)

\section{1) Allerhand Mojżesz}

$\mathrm{dr}$;

ok. 2 tys. tomów;

prawo, książki ilustrowane z XVIII i XIX w., grafika polska i obca;

E.Chwalewik: Zbiory polskie. T. 1. Warszawa 1926, s. 421.

2) Altenberg Alfred (1877 Warszawa - 8 V 1924 Lwów)

księgarz, nakładca;

ok. 2 tys. tomów;

literatura piękna, pierwsze wydania klasyków polskich, okazy sztuki drukarskiej, wydawnictwa artystyczne;

E.Chwalewik: Zbiory polskie. T. 1. Warszawa 1926, s. 421.

3) Anczyc Wacław Zygmunt (4 Il 1886 Warszawa - 27 XI 1938 Kraków) historyk, działacz społeczny, drukarz;

10 tys. tomów;

tematyka fachowa i beletrystyka; 
ofiarowane szkolnej bibliotece Publicznej Dokształcajacej Szkoły Zawodowej w Krakowie;

H.Mortkowicz-Olczakowa: Pod znakiem kloska. Warszawa 1962.

4) Angellowicz Antoni (1756 w. Hryniów k. Bóbrki - 9 VIII 1814 Lwów) $\mathrm{dr}, \mathrm{ks}$. arcybiskup, metropolita unicki, prof. teologii na Uniwersytecie Lwowskim;

ok. 8 tys. tomów;

teologia;

dar dla Biblioteki Kapituły Greckokatolickiej we Lwowie;

Polski Słownik Biograficzny T. 1, s. 112, E.Chwalewik: Zbiory polskie. T. 1. Warszawa 1926, s. 381.

5) Badeni Stanisław (1 I 1877 Radziechów k. Tarnopola - 28 VII 1943 Korczyna k. Krosna)

prawnik, historyk, wydawca pism, działacz społeczny i polityczny, wiceprezes Towarzystwa Przyjaciół Biblioteki Jagiellońskiej, ziemianin;

10 tys. tomów i znaczny zbiór czasopism - nabyte od K.Gubrynowicza (1 XI 1876 Lwów - 9 IV 1958 Wrocław), księgozbiór ojca Stanisława (1912), w większości własna biblioteka w Radziechowie i część biblioteki Miera (razem 500 t.);

$\mathrm{z}$ różnych dziedzin wiedzy, własna biblioteka z zakresu literatury pięknej, nauk humanistyczno-społecznych, pamiętniki;

ofiarowane w 1914 r. Bibliotece Ossolineum we Lwowie, zaś własna biblioteka i po Mierze przekazane wyposażonemu przez siebie Naukowemu Instytutowi Katolickiemu w Krakowie (po II wojnie światowej wcielona do Biblioteki Miejskiej w Krakowie);

E.Chwalewik: Zbiory polskie. T. 2. Warszawa 1927, s. 139; A.Fischer: Zaklad Narodowy imienia Ossolińskich. Zarys dziejów. Lwów 1921, s. 82.

6) Balzer Oswald Marian (23 I 1858 Chodorów k. Kaniowa - 11 I 1933 Lwów)

historyk, profesor i rektor Uniwersytetu Lwowskiego, inicjator organizowania bibliotek naukowych na prowincji;

1400 druków, 70 rękopisów;

głównie z zakresu historii prawa polskiego;

ofiarowane Bibliotece Zakładu Narodowego im. Ossolińskich; 
Sprawozdania Wydziały Towarzystwa dla Popierania Nauki Polskiej we Lwowie 1903-18. Lwów 1903-1919; L.Halban: Oswald Balzer czlowiek $i$ dzieto. "Roczniki Humanistyczne" 1960, z. 4, S. 109-117; J.Korpała: Z dziejów bibliotek w Galicji. w: Z zagadnień teorii i praktyki bibliotekarskiej. Wrocław 1961.

\section{7) Bandtkie Jerzy Samuel (24 XI 1768 Lublin - 11 VI 1835 Kraków)}

historyk, językoznawca, nauczyciel, bibliotekarz w Bibliotece Jagiellonskiej;

2699 dzieł;

z zakresu historii, językoznawstwa, literatury;

przekazane Bibliotece Jagiellońskiej;

K.Lewicki: Sprawa powolania Jerzego Samuela Bandtkiego na stanowisko dyrektora Biblioteki Jagiellońskiej. ,Sobótka” 1950, s. 172-183.

8) Baraniecki Adrian (4 XI 1828 Jarmolince, Podole - 15 X 1891 Kraków)

lekarz, działacz społeczny, organizator Muzeum TechnicznoPrzemysłowego w Krakowie, Wyższych Kursów dla Kobiet im. A. Baranieckiego, członek Akademii Umiejętności;

30 tys. t. w 1921 r. przy Muzeum Techniczno-Przemysłowym i 3 tys. t. przy Wyższych Kursach dla Kobiet;

z zakresu różnych dziedzin wiedzy, w tym też z techniki;

ofiarowane Muzeum Techniczno-Przemysłowemu, m.in. Bibliotece Akademii Umiejętności, Bibliotece Jagiellońskiej;

J.Wdowiszewski: A.Baraniecki. Kraków 1891; E.Chwalewik: Zbiory polskie. T. 1. Warszawa 1926, s. 242-244.

\section{9 ) Barewicz Eugeniusz (ok. 1863 - 18 VI 1917 Lwów)}

dziennikarz, urzędnik pocztowy;

10 tys. t. odziedziczone po ojcu i bracie;

z zakresu prawa, historii sztuki, botaniki, literatura (leopolitana);

zapisane jako depozyt wieczysty w $1916 \mathrm{r}$. Gminie m. Lwowa (stały się m.in. podwaliną Biblioteki Królewskiego Stołecznego m. Lwowa później Biblioteki Miejskiej);

K.Badecki: Biblioteka Miejska. w: Publiczne biblioteki lwowskie. Lwów 1926, s. 59. 
10) Barwiński Eugeniusz ( 3 I 1874 w. Postołówka k. Husiatyna - 16 V 1947 Kraków)

bibliotekarz lwowskiej Biblioteki Uniwersyteckiej, dyrektor Archiwum Państwowego we Lwowie, kustosz Archiwum Państwowego w Krakowie, historyk, bibliograf;

2,5 tys. dzieł, stare druki;

z zakresu historii, druki dotyczące czasów Zygmunta III i Władysława IV, turcyki z końca XVI w., synody XVI i XVII w., dissidentica, heraldyka, bibliografia;

sprzedane Bibliotece Słowiańskiej w Pradze;

A.Kamiński: Eugeniusz Barwiński, historyk, bibliotekarz i archiwista. „Archeion" 1959, s. 95-121.

11) Batowski Aleksander Konstanty (14 I 1799 w. Kulików pow. Żółkiew - 10 I 1862 w. Doroszów)

historyk, publicysta, działacz polityczny, ziemianin;

5135 druków, w tym 4778 poloników, 107 rękopisów, 219 map i kart geograficznych, ponadto 9365 rycin i czasopisma emigracyjne; $\mathrm{z}$ różnych dziedzin, głównie dotyczące Polski;

nabyte zostały głównie przez W.Baworowskiego, S.Borkowskiego i M.Pawlikowskiego;

K.Lewicki: Aleksander Konstanty Batowski (1799-1862) - historykwydawca, bibliofil-kolekcjoner. „Roczniki Biblioteczne” 1970, s. 250293.

12) Baworowski Wiktor (1816 w. Kotłów k. Złoczowa - 3 XII 1894 Lwów)

urzędnik w Namiestnictwie we Lwowie, ziemianin;

15571 wol., 110 dyplomów, 1080 rękopisów, w tym 2 iluminowane z XII w., Kronika W.Kadłubka (Biblioteka Fundacji Baworowskich);

z zakresu historii, filozofii z końca XVIII i pocz. XIX w., polonica, slavica. czasopisma emigracyjne;

udostępniane za pośrednictwem Biblioteki Ossolineum, po II wojnie światowej część przypadła Ossolineum, większość została we Lwowie;

A. Batowski: O Bibliotece i przyszlym zakladzie naukowym im. Baworowskich. "(zas" 1861, nr 84-86; W.Kętrzyński: Biblioteka Wiktora hr. Baworowskiego we Lwowie. "Teka Konserwatora" 1892, s. 40-48; R.Kotula: Biblioteka Fundacji W. hr. Baworowskiego. w: Publiczine bi-

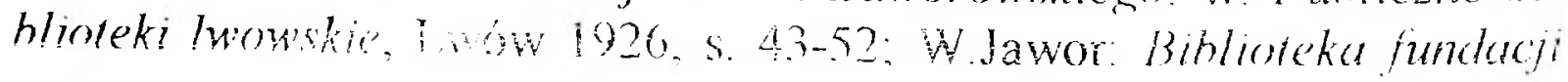


Wiktora hr. Baworowskiego we Lwowie - praca magisterska (Biblioteka Instytutu Bibliotekoznawstwa Uniwersytetu Wrocławskiego 1985).

13) Bayer Julian Kazimierz ( 16 II 1806 Kraków - 15 II 1872 Warszawa) matematyk, statystyk, nauczyciel; ok. 1500 dzieł, 18 rękopisów z XVIII i XIX wieku; matematyka, astronomia, astronomia fizyczna; ofiarowane Towarzystwu Naukowemu Krakowskiemu (Biblioteka Polskiej Akademii Nauk w Krakowie);

F. Kucharzewski: Nasza najdawniejsza ksiazka o miernictwie. Warszawa 1926, s. 7-8, 22-23.

14) Bernacki Ludwik (12 VI 1882 Jaworów - 19 IX 1939 Lwów) historyk literatury i teatru, wydawca, bibliotekarz, bibliograf, dyrektor Biblioteki Zakładu Narodowego im. Ossolińskich;

4 tys. tomów;

z zakresu bibliografii, bibliofilstwa, historii, historii literatury ze szczególnym uwzględnieniem drugiej połowy XVIII w., krasiciana;

ofiarowane po śmierci właściciela przez żonę Marię z Pochwalskich Ossolineum;

E.Chwalewik: Zhiory polskie. T. 1.Warszawa 1926, s. 422; Biblioteka Ossolińskich: rpsy 7028-7078/1II; F.Pajączkowski: Zaklad Narodowy im. Ossolińskich (1928-1948). "Rocznik Zakladu Narodowego im. Ossolinskich" 3: 1948; W.Olszewicz: Ludwik Bernacki. "Roczniki Biblioteczne" 1963 , z. 1-2, s. 177-189.

15) Biesiadecki Franciszek Ksawery (28 II 1869 Kraków - 1940 Lwów) działacz polityczny i społeczno-kulturalny, poseł do Rady Państwa i na Sejm Krajowy, współzałożyciel czasopisma „Ekslibris”, ziemianin;

5000 tomów, mapy, ekslibrisy, stare druki; historia sztuki, historia, numizmatyka, druki bibliofilskie; ofiarowane Bibliotece Zakładu Narodowego im. Ossolińskich, Jagiellońskiej, Bibliotece Katolickiego Uniwersytetu Lubelskiego w Lublinie, Bibliotece Muzeum Przemysłowego w Krakowie i in.;

Encyklopedia Wiedzy o Ksiazce. Wrocław 1971, s. 306-307.

16) Borkowski Jerzy Sewer Teofil Dunin( 1 X 1856 Dubiecko k. Przemyśla - 23 X 1908 w. Młyniska nad Dniestrem)

polityk, heraldyk, działacz spoieczny: 
20 tys. tomów we Lwowie, w tym stare druki, rękopisy, archiwalia, część przeniesiona do Gródka nad Dniestrem;

przede wszystkim z zakresu historii, genealogii i heraldyki;

po śmierci właściciela przeszły na własność rodziny w Gródku;

E.Chwalewik: Zbiory polskie. T. 1. Warszawa 1926, s. 115.

17) Borkowski Stanisław Jan Nepomucen Dunin ( $3 \mathrm{~V} 1782$ w. Ruda Małopolska - 29 XII 1850 Lwów)

geolog, mineralog, pisarz, zasłużony wokół uruchamiania fundacji Ossolińskich we Lwowie, ziemianin;

ok. 6 tys. tomów z siedzibą w majątku rodzinnym Winniczki k. Lwowa;

z zakresu historii, historii literatury, przyrody;

ofiarowane w 1848 r. Bibliotece Uniwersytetu we Lwowie;

F.Radziszewski: Wiadomość historyczno-statystyczna o znakomitszych bibliotekach i archiwach publicznych i prywatnych. Kraków 1875, s. 116.

18) Branicki Aleksander (1821 - 19 IX 1877 Nicea)

podróżnik, ziemianin;

księgozbiór (ok. 3000 dz., 71 rękopisów, 41 dyplomów), kupiony od A.E.Koźmiana (1804-1864) z Piotrowic i w 1866 r. ulokowany w Suchej (Żywieckie), powiększony o zbiór Feliksa Wesołowskiego;

głównie z zakresu historii ojczystej, literatury, stare druki, rękopisy;

przekazany żonie Annie z Hołyńskich Branickiej (1824-1907), następnie nabyty przez syna Władysława Branickiego (1848-1914), powiększony przez niego i przekazany w 1932 r. Juliuszowi Tarnowskiemu (w związku z ożenkiem z jego córką Anna);

Archiwum Główne Akt Dawnych sygn. 52/67; M.Żmigrodzki: Kilka slow o zbiorach hr. Branickich w Suchej. "Przewodnik Bibliograficzny" 1910, s. 143; M.Sawicka: Biblioteka na zamku w Suchej. „Myśl Narodowa" 1926, nr 37, s. 151-152; M.Kalita: Dzieje Biblioteki hr. Branickich $w$ Suchej - praca magisterska (Instytut Bibliotekoznawstwa Uniwersytetu Wrocławskiego 1985); W. Jabłońska: Inwentarze i katalogi bihlioteczne w zbiorach rękopiśmiennych Biblioteki Zakladu Narodowego im. Ossolinskich. "Ze skarbca kultury" 1969, s. 114-115. 
19) Brodowicz Maciej Józef (24 II 1790 Grzymałów k. Skałata - 22 I 1885 Kraków)

lekarz, prof., rektor Uniwersytetu Jagiellońskiego;

1861 dz. (2914 t.), 7 atlasów, 3 rękopisy,

przeważnie o tematyce lekarskiej;

ofiarowane w 1865 i 1884 r. Bibliotece Jagiellońskiej;

W.Berbelicki: Dary dla Biblioteki Jagiellonskiej w latach 1868-1904. „Biuletyn Biblioteki Jagiellońskiej” 1959, s. 72; K.Mrozowska: J.M.Brodowicz. Wrocław 1971, s. 173-175.

20) Bruchnalski Kazimierz (XIX wiek)

wizytator szkolny;

1579 tomów ( 1364 dzieła);

filozofia, psychologia, pedagogika w różnych językach;

dar dla Biblioteki Publicznej miasta Lwowa w 1925 roku;

E.Chwalewik: Zbiory polskie. T. 1. Warszawa 1926, s. 381.

21) Bruchnalski Wilhelm Adolf (21 V 1859 - 6 XII 1938 Lwów)

historyk literatury i języka polskiego, bibliograf, prof. Uniwersytetu Lwowskiego, prezes Towarzystwa Literackiego im. A.Mickiewicza;

ok. 8 tys. tomów, w tym stare druki;

historia literatury polskiej i kultury;

przekazane w większości Katedrze Historii Literatury Polskiej Uniwersytetu Lwowskiego;

E.Chwalewik: Zbiory polskie. T. 1. Warszawa 1926, s. 422.

22) Bursa Stanisław Władysław (22 VIII 1865 Obertyn k. Horodenki 29 V 1947 Kraków)

kompozytor, pedagog, redaktor;

bogaty księgozbiór (nieznana dokładnie liczba tomów), w tym rękopisy;

muzyka, literatura, historia sztuki, nuty, czasopisma;

część ofiarowana Bibliotece Jagiellońskiej, resztę (ok. 700 wol.) zakupiła od rodziny w 1862 r. Biblioteka Państwowej Wyższej Szkole Muzycznej w Katowicach;

Biblioteka Jagiellońska: rkps 7534; Słownik muzyków polskich. red. Józef Chomiński. Kraków 1964. T. 1. 
23) Chalubiński Tytus (29 XII 1820 Radom - 4 XI 1889 Zakopane)

lekarz, botanik, twórca w 1878 r. Towarzystwa Tatrzańskiego i Biblioteki przy nim;

duży księgozbiór (nieznana dokładna liczba tomów); głównie carpatica;

podstawa Biblioteki założonego po śmierci Muzeum Tatrzańskiego jego imienia w Zakopanem, 596 książek ofiarowanych dla Biblioteki Towarzystwa Oświaty Ludowej w Nowym Targu, niektóre dla Muzeum Karpackiego w Popradzie;

E.Chwalewik: Zbiory polskie. T. 2. Warszawa 1927, s. 532-533; S.Sierotwiński: Z wizyla w bibliotekach zakopiańskich. "Bibliotekarz" 1953 , s. 147-152.

24) Chyliński Konstanty ( $14 \times 1881$ w. Zmierzynka Wielka, pow. Winnica - 5 II 1939 Lwów)

historyk, prof. Uniwersytetu Lwowskiego, organizator m.in. biblioteki Katolickiego Uniwersytetu Lubelskiego;

ok. 6 tys. pozycji;

historia, literatura;

ofiarowane Bibliotece Katolickiego Uniwersytetu Lubelskiego;

E.Chwalewik: Zhiory polskie. T. 1. Warszawa 1926, s. 423.

25) Cieński Udalryk Mikołaj (4 VII 1720 na Rusi Czerwonej - 5 VIII 1872 w. Okno k. Horodenki)

ziemianin;

biblioteka w Oknie, odziedziczona po ojcu Maurycym Józefie Cieńskim (1749-1817), powiększona o część księgozbioru J.Dzierzkowskiego, licząca kilka tysięcy tomów;

z różnych dziedzin wiedzy, polonica z XVI, rękopisy, obrazy, ryciny, muzealia i in.;

po śmierci właściciela pod opieką jego syna Ludomira Ludwika Juliusza Cieńskiego (1822-1917), w latach 1917-1920 zbiory częściowo zniszczone, do Biblioteki Zakładu Narodowego im. Ossolińskich we Lwowie trafiło kilkaset ksiązek, w tym 11 inkunabułów, ponadto 16 rękopisów;

E.Chwalewik: Zbiory polskie. T. 2. Warszawa 1927, s. 23; W.Jabłońska: Inwentarze i katalogi biblioteczne $w$ zhiorach rękopiśmiennych Biblioteki Zakladu Narndowego im. Ossolińskich. .7e skarhcakulury" $1969,2.10$ s. 126-127 
26) Czartoryski Adam Jerzy (14 I 1770 Warszawa - 1861 Montfermeil, Francja)

mąż stanu, współtwórca Bibliotki Polskiej w Paryżu, ziemianin;

1972 rękopisy, 16815 druków polskich, 22110 druków obcych; różne dziedziny wiedzy;

część rękopisów i książek wywieziona w 1831 r. do Petersburga, część do Warszawy i Sieniawy - przejęta przez Władysława;

M.Handelsman: ('zartoryski Adam Jerzy ksiazę. W: Polski Slownik Biograficzny. T. 4. 1937, s. 257-269.

27) Czartoryski Witold Kazimierz (10 III 1876 Paryż - 28 X 1911 tamże)

podróżnik, ziemianin z zamkiem Côte de Grâce k. Honfleur w Normandii;

16 tys. dz. w ponad 25 tys. tomów w różnych językach, rękopisy, czasopisma;

z zakresu historii, filologii, historii literatury, filozofii, religioznawstwa, dziejów wolnomularstwa, okultyzmu, geografii, nauk ścisłych i in.;

ofiarowane w 1923 r. przez brata Adama Ludwika Czartoryskiego Bibliotece Uniwersytetu Lwowskiego, dublety (ok. 2000 tomów) - Bibliotece Czartoryskich w Krakowie, dział marynarski (ok. 700 dz.) Państwowej Szkole Głównej Marynarki Polskiej;

E.Chwalewik: Zbiory polskie. T. 1. Warszawa 1926, s. 123-124; W.Gąsiorowski: Biblioleka ks. Witolda Kazimierza Czarloryskiego. „Swiat" 1910, nr 4; S.Mękarski: Królewski dar dla Lwowa. „Slowo Polskie" 1923, nr 233; Biblioteka Czartoryskich w Krakowie. rpsy Ew. 1432, Ew. 1433.

28) Czartoryski Wladyslaw (3 VII 1828 Warszawa - 23 VI 1894 Boulogne sur Seine, Francja)

działacz polityczny, ziemianin;

księgozbiór otrzymany po ojcu poszerzony znacznie, tak, że w $1894 \mathrm{r}$. liczył 100 tys. tomów, w tym ok. 35 tys. poloniców, 2.400 inkunabułów i druków polskich z XVI w., rękopisy, dyplomy;

różne dziedziny wiedzy;

Biblioteka Polska w Paryżu 1893 r. przekształcona w paryska Stację Naukową Akademii Umiejętności w Krakowie, uprzednio poszerzona częścią zbiorów z. Sieniawy, niektóre zbiory krajowe w 1875-76 ulokowano w Krakowie, a 1899 r. caly ksiegozbior. 
K.Buczek: Z przeszlości Biblioteki Muzeum XX C.zartoryskich oraz przyczynki do dziejów biblioteki paryskiej. Kraków 1936.

29) Czolowski Aleksander (27 II 1865 Bakończyce k. Przemyśla - 17 VII 1944 Lwów)

historyk, archiwista, dyrektor Archiwum Akt Dawnych m. Lwowa, organizator w 1917 r. Biblioteki Królewskiej st. m. Lwowa;

$5000 \mathrm{dz}$;

niektóre druki z w. XV-XVI, rękopisy archiwalne i biblioteczne, wiele akt papierni w Fujnie, $\mathrm{z}$ archiwum Mniszchów, Woroniczów, Działyńskich i in., ryciny, rysunki, mapy;

2500 rękopisów ofiarowane w 1936 r. Bibliotece Ossolińskich, inne wcielone po wojnie do zbiorów Biblioteki Narodowej, archiwalia do Archiwum Głównego Akt Dawnych;

J.Zieliński: Aleksander Czolowski w 40-lecie pracy. w: Studia Lwowskie. Lwów 1932, s. 367-385.

30) Dąbczańska Helena - zamężna Budzynowska ( 3 I 1863 Lwów - 7 I 1956 Kraków)

kolekcjonerka muzealiów, organizatorka muzeum we Lwowie;

12 tys. tomów (w tym 3 tys. poloników, 6 tys. książek francuskich) w 1906 r., 22 tys. tomów w 1918;

z zakresu różnych dziedzin, literatura polska i obca, jesuitica, inkunabuły;

przekazane Muzeum Narodowemu na Wawelu, Bibliotece Muzeum Przemysłowego w Krakowie, Muzeum Jana III we Lwowie i innym muzeom;

J.Białynia-Chołodecki: Dabczańscy i Jan Zalplachta-Zapalowicz. Lwów 1913; H.Dąbczańska: Pamiętnik. Cz. 1. Oprac. J.Fijałek. „Rocznik Biblioteki Polskiej Akademii Nauk Krak." 1963, s. 307-360; Na Wawel. Lwów 1906; M.Hałon: Księgozbiór Heleny Dabczańskiej - praca magisterska (Instytut Bibliotekoznawstwa Uniwersytetu Wroclawskiego, 1980).

\section{1) Dąmbski (Dąbski) Lukasz (zm. przed 1826)}

sekretarz stanów galicyjskich, właściciel folwarku k. Lwowa;

$2700 \mathrm{dz}$. (ok. 7100 wol.) z siedzibą prawdopodobnie w Cetnerówce; głównie z XVIII w. (nieco z XVIl i pocz. XIX w.), głównie w j. fran- 
cuskim, niemal z wszystkich dziedzin wiedzy, najliczniej o retoryce i poezji;

w 1825 (lub 1822) ofiarowano Tomaszowi Dambskiemu;

Biblioteka Zakładu Narodowego im. Ossolińskich, rps 1608/IV (trzy spisy książek);W.Jabłońska: Inwentarze i katalogi biblioteczne $w$ zhiorach rękopiśmiennych Biblioteki Zakladu Narodowego im. Ossolińskich. „Ze skarbca kultury” 1969, z. 20, s. 118-120.

\section{2) Dąmbski Tomasz (zm. XI 1829)}

członek stanów galicyjskich, szambelan Stanisława Augusta;

$200 \mathrm{dz}$. (ok. 350 wol.) powiększone zbiorem po Łukaszu Dąmbskim (ok. $2700 \mathrm{dz}$ );

$\mathrm{z}$ różnych dziedzin wiedzy i $\mathrm{w}$ różnych językach (francuski, niemiecki, polski, łacina);

nabyte wraz ze zbiorami po Łukaszu Dąmbskim przez Władysława Dąmbskiego;

Biblioteka Zakładu Narodowego im. Ossolińskich: rsp 1609/III i rps 1610/III (Spisy książek i inne materiały).

\section{3) Dąmbski Wladysław (XIX w.)}

marszałek powiatowy i deputowany do Sejmu Galicyjskiego;

$2628 \mathrm{dz}$. (7 048 wol.) i 697 sztychów z XVIII w.;

$\mathrm{z}$ różnych dziedzin wiedzy;

w $1871 \mathrm{r}$. ofiarowane Bibliotece Jagiellońskiej, skatalogowane w 1872 przez Żegotę Pauli;

Biblioteka Zakładu Narodowego im. Ossolińskich: rps 4286/III; J.Przygocka: Żegota Pauli - zapomniany bibliotekarz $i$ bibliograf. "Roczniki Biblioteczne" 1970, s. 735.

34) Doliński Jarosław (16 XII 1881 Jeziorzany k. Borszczowa, Galicja Wsch. - 25 XI 1971 Kraków)

chemik w krakowskiej Gazowni Miejskiej, numizmatyk,

kilka tysięcy tomów (nieznana dokładna liczba tomów);

historia sztuki, pamiętniki, pierwsze wydania klasyków, edycje bibliofilskie;

L.Gocel: Przypadki Jej Królewskiej Mości Ksiqżki. Wrocław 1963, s. $330-331$. 
35) Drągowski Zygmunt Stanisław (1843 Ostrożec k. Dubna - 22 VII 1915 Lwów)

farmaceuta, działacz społeczny i narodowy;

ponad 4500 tomów;

głównie dawne czasopisma;

część ofiarowana Towarzystwu Szkoły Ludowej, leopolitana - Bibliotece przy Archiwum Akt Dawnych we Lwowie (Późniejsza Biblioteka Miejska), pozostałe 4506 tomów nabyła w 1928 r. gmina m. Lwowa do Biblioteki Miejskiej;

E.Chwalewik: Zbiory polskie. T. 1. Warszawa 1926, s. 381; K.Badecki: Biblioteka Publiczna m. Lwowa. Lwów 1939, s. 18.

36) Dzieduszycki Józef Kalasanty (3 VII 1776 - 19 VI 1847 Lwów) założyciel Biblioteki Poturzyckiej, ziemianin w Poturzycy k. Sokala; kilkunastotysięczny księgozbiór, archiwalia i grafika;

historia Polski, literatura polska, łacińska (zwłaszcza druki XVI XVII) i francuska, zbiór rozporządzeń austriackich z XVIII i I poł. XIXw., odziedziczona przez syna Włodzimierza;

M.Tyrowicz: Dzieduszycki . Józef Kalasanty. w: Polski Slownik Biograficzny. T. 6. Kraków 1946, s. 111; K.Kantecki: Z aulografów Biblinteki Poturzyckiej. "Przewodnik Naukowo-Literacki" 1878, s. 79-96, E.Chwalewik: Zbiory polskie. T. 1. Warszawa 1926, s. 379-380, 398399; Biblioteka Zakładu Narodowego im. Ossolińskich: rps. 1839/11.

37) Dzieduszycki Wlodzimierz (22 VI 1825 Jaryszów, Podole - 18 IX 1899 Poturzyca)

przyrodnik, etnograf, założyciel Muzeum im. Dzieduszyckich, ziemianin;

księgozbiór odziedziczony po ojcu, powiększony, liczący w $1861 \mathrm{r}$. 14505 tomów, w 1925 r. - 50 tys. dz., 1,8 tys. autografów i in.;

głównie $\mathrm{z}$ zakresu historii Polski, literatury i nauk przyrodniczych, szkolnictwa, druki unikatowe np. Statula J.Łaskiego;

przeniesione w $1857 \mathrm{r}$. do Lwowa, w $1858 \mathrm{r}$. otwarte w formie biblioteki, głównie studentom, w jesieni 1939 r. wcielone do Biblioteki Ukraińskiej Akademii Nauk, część przechowywana w Bibliotece Ossolińskich;

M.Des Loges: Biblioteka ()rdynacji hr. Dzieduszyckich. w: Publiczne bihlioteki lwowske Lwów 1926, s. 53-55; W Jablonska: Inwenture

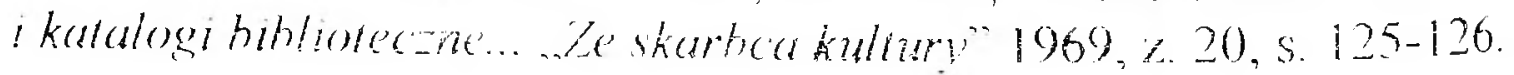


38) Dzierzkowski Józef, Dobek (11 III 1764 Siemianowice k. Kołomyi 28 I 1830 Lwów)

adwokat, polityk, wicemarszałek Stanów Galicyjskich;

spory księgozbiór, kodeksy rękopiśmienne XV - XVIII w., mszały polskie i ruskie, kazania, bizantynica, armenica;

z zakresu historii (40\%), filozofii, przyrodoznawstwa, literatury pięknej i gospodarstwa wiejskiego;

cimelia zapisane Bibliotece Zakładu Narodowego im. Ossolińskich, reszta sprzedana na licytacji (1840 r.) i niektóre dzieła przeszły w ręce rodziny;

Biblioteka Zakładu Narodowego im. Ossolińskich: rps. 6772/III; K.Stefanicka: Dwóch Józefów Dzierzkowskich w historii Biblioteki Zakladu Narodowego im. Ossolińskich. „Ze skarbca kultury” 1967, z. 19, s. 62-81; J.Flicińska: Biblioteka.Józefa Dzierzkowskiego (1764-1830) praca magisterska (Instytut Bibliotekoznawstwa Uniwersytetu Wrocławskiego).

39) Fedorowicz Władysław Walenty ( $26 \mathrm{~V} 1845 \mathrm{w}$. Bielanówka k. Tarnopola - 21 I 1918 w. Okno k. Skałata, Tarnopolskie)

literat, historyk, polityk, w 1873-1877 prezes Towarzystwa Wydawniczego Proświta we Lwowie;

20 tys. tomów, w tym stare druki, ryciny, rysunki m.in. Grottgera w rodzinnym majatku Oknie;

z zakresu różnych dziedzin;

spalone podczas I wojny światowej;

E.Chwalewik: Zbiory polskie. T. 2. Warszawa 1916, s. 24.

40) Fischer Adam Robert (7 VI 1889 Przemyśl - 22 XII 1943 Lwów) etnolog, bibliotekarz, bibliograf, prof. Uniwersytetu Lwowskiego; 6 tys. woluminów;

krajoznawstwo, ludoznawstwo;

ofiarowane Bibliotece Towarzystwa Ludoznawczego we Lwowie, obecnie są własnością Biblioteki Polskiego Towarzystwa Ludoznawczego im. Jana Czekanowskiego w Wrocławiu;

E.Chwalewik: Zbiory polskie. T. 1. Warszawa 1926, s. 423; Polski Slownik Biograficzny. T. 7, s. 18-19. 
41) Formaniosz Michał (1814 - 17 VII 1884)

ksiądz;

10209 tomów dzieł polskich i obcych;

z zakresu nauk humanistycznych;

zapisany testamentem Bibliotece Uniwersyteckiej we Lwowie;

Biblioteka Uniwersytecka Lwów: rps. 428 IV k. 355; Biblioteka Ossolińskich: I.Hoelzel: Ze wspomnień o bibliofilach 1870-1936. Lwów 1937, 14 s., maszynopis powiel.

42) Friedlein Daniel Edward (26 VI 1802 Kraków - 26 VII 1855 Krzeszowice)

księgarz, nakładca, właściciel drukarni;

cenne zbiory sztuki, mapy, rzadkie druki, głównie polonica,

głównie $\mathrm{z}$ zakresu historii drukarstwa, papiernictwa, introligatorstwa;

spalone w czasie pożaru Krakowa w 1850 r., nieliczna część ocalała przejęta przez syna Józefa Edwarda Friedleina;

E.Chełstowski: Katalogi księgarskie Friedleinów. „Księgarz” 1960, nr 1-2, s. 19-20.

43) Friedlein Józef Edward (4 II 1831 Kraków- 25 V 1917 tamże)

księgarz, nakładca, kolekcjoner;

10 tys. tomów, 2000 portretów królów i książąt polskich, mapy, stare druki od XVI w., rękopisy i in.;

z zakresu geologii, numizmatyki, prawa, przyrody, paleontologii;

po śmierci właściciela przejęte przez wnuka J.Münnicha;

F.Radziszewski: Wiadomość historyczno-statystyczna o znakomitszych bibliotekach $i$ archiwach publicznych i prywatnych. Kraków 1875, s. 32; S.Banach: Materialy ikonograficzne ze zbiorów J.F. w Państwowych Zbiorach Sztuki na Wawelu. W: Studia do dziejów Wawelu. T. 1. Kraków 1955, s. 382-384; K.Laszkiewicz: Józef Edward Friedlein prezydent m. Krakowa - księgarz, nakladca, kolekcjoner - praca magisterska (Wyższa Szkoła Pedagogiczna w Krakowie 1983).

44) Fusiecki Aleksander Wojciech (1805 w. Kamień, Poznańskie - 29 III 1862 Kraków)

ksiegarz, nakładca, uczestnik rewolucji 1846 i 1848;

3764 tomy i 5 tys. rycin, grafik; 
z zakresu historii literatury polskiej, w tym prawie komplet politycznych druków krakowskich wydanych za panowania Zygmunta I i Zygmunta Augusta;

sprzedane książki Adamowi Potockiemu (1822-1872);

Biblioteka Jagiellońska: Klepsydra oraz rpsy: 5528, 5564 t. 1, 5694 (listy K.W.Kielisińskiego do Fusieckiego), 6456 IV k. 211-212, 6929 IV, 6984 I k., 18, 27-28.

45) Gawalewicz Marian (21 X 1852 Lwów - 26 V 1910 tamże)

powieściopisarz, publicysta, dyrektor teatru w Warszawie, Łodzi i Lwowie;

3500 tomów;

z zakresu dramaturgii polskiej i obcej, literatury, historii filozofii;

w 1910 zapisane gminie miasta Lwowa (podwalina zorganizowanej w 1917 r. Biblioteki Królewskiego Stołecznego m. Lwowa);

K.Badecki: Biblioteka Miejska. w: Publiczne biblioteki lwowskie. Lwów 1926, s. 59.

46) Giebultowski Kazimierz ( 8 VIII 1878 Tarnobrzeg - 12 IV 1959 Lwów)

nauczyciel polonista gimnazjum w Krakowie, wydawca, bibliotekarz, bibliofil, działacz społeczno-oświatowy w Towarzystwie Uniwersytetu Ludowego im. A.Mickiewicza w Krakowie;

bogaty księgozbiór;

z zakresu historii, literatura polska i językoznawstwo;

J.Korpała: Biblioteka Publiczna Towarzystwa Lniwersytetu Ludowego im. A.Mickiewicza. "Roczniki Biblioteki Narodowej" 1966, nr 2, s. 379-396; W.Olszewicz: Kazimierz (jiebultowski. "Roc:niki Biblioteczne" 1967, s. 35-45.

47) Gostkowska Józefa z domu Zawadzka (1760 - 23 I 1850 Kraków) wlaścicielka biblioteki;

1329 dz. w 2853 tomach, w tym 398 starych druków i 11 rękopisów; dzieła podróżnicze, przewodniki, dzieła prawno-ekonomiczne; otrzymane po mężu Wincentym Gostkowskim (1746-1818, radcy Trybunału Apelacyjnego we Lwowie), zapisane w 1832 r. Bibliotece Jagiellońskiej; 
Biblioteka Jagiellońska: rps. 3442; A.Lewicka-Kamińska: Narastanie zasobu starych druków Biblioteki Jagiellońskiej. "Przeglad Biblioteczny" 1964, s. 215.

48) Gottlieb Wojciech (1884 Praga czeska - 3 V 1941 Lwów)

socjolog, księgarz, wydawca, lektor Akademii Medycyny Weterynaryjnej, prof. Państwowej Szkoły Ekonomiczno-Handlowej we Lwowie;

5 tys., tomów;

przeważnie filozofia i socjologia;

E.Chwalewik: Zbiory polskie. T. 2. Warszawa 1927, s. 552 (Dopełnienia); Polski Slownik Biograficzny. T. 8. s, 387.

49) Helcel Antoni Zygmunt (2 XI 1808 Kraków - 31 III 1870 tamże)

prof. Uniwersytetu Jagiellońskiego, prawnik, historyk, wydawca, właściciel drukarni, polityk;

znaczny księgozbiór, rękopisy prac, papiery osobiste i rodzinne;

z zakresu historii prawa;

zakupione w 1870 r. przez A.Potockiego do biblioteki w Krzeszowicach, przekazane w 1945 r. Bibliotece Jagiellońskiej i Bibliotece Narodowej, zaś papiery osobiste i rodzinne oraz inne Bibliotece Akademii Umiejętności (znajdują się w Bibliotece PAN w Krakowie);

Biblioteka Narodowa w latach 1945-1956. Warszawa 1958, s. 60; Rękopisy w Bibliotece Ossolińskich we Wrocławiu, w Bibliotece PAN w Krakowie $i$ in.

50) Jaworski Franciszek (21 XI 1873 Gródek Jagielloński - 18 III 1914 Lwów)

dziennikarz, historyk, archiwista;

cenne zbiory (nieznana dokładna liczba tomów);

encyklopedie, słowniki, biografie, dzieła z zakresu historii (pamiętniki, stare kroniki, leopolitana, życiorysy itp.);

rozproszone po śmierci właściciela;

B.Janusz: Zbiory Franciszka .Jaworskiego we Lwowie. "Ziemia" 5: 1914/1919, nr 14; Korespondencja Jaworskiego w Bibliotece Ossolin'skich i Bibliotece Narodowej. 
51) Kallenbach Józef Henryk (24 XI 1861 Kamieniec Podolski - 12 IX 1929 Kraków)

prof. uniwersytecki, historyk literatury, bibliotekarz Akademii Umiejętności w Krakowie;

6 tys. tomów;

z zakresu historii i krytyki literackiej;

po śmierci właściciela przeszły na własność rodziny;

E.Chwalewik: Zbiory polskie. T. 1. Warszawa 1926, s. 250; Józefowi Kallenbachowi ku uczczeniu +10-letniej pracy naukowej. Lwów 1925.

52) Kasprowicz Jan ( 12 XII 1860 w. Szymborze k. Inowrocławia 1 VIII 1926 Harenda k. Zakopanego)

poeta, dramaturg, prof. i rektor Uniwersytetu Lwowskiego;

$2609 \mathrm{dz}$. w 4719 tomach - z siedzibą w Harendzie;

z zakresu różnych dziedzin wiedzy, głównie literatury, historii, religii i filozofii, starodruki XV-XVIII w., dział czasopism;

przekazana w 1929 r. Poznaniowi;

(I.B.): Losy biblioteki Kasprowiczowskiej. „Kurier Poznański” 1928, nr 500, s. 17; T.Grabowski: Biblioteka Kasprowiczowska w Poznaniu. "Tęca" 1930, z. 43; W.Kwiatkowski: (jutenberg na Harendzie. "Tygodnik Powszechny" 1961, nr 13, s. 8; Z.Gaca-Dąbrowska: W sprawie "lzby Kasprowiczowskiej". "Tygodnik P'owszechny" 1963, nr 51/52; S.Winch: Ksiqzka w zyciu i Iwórczości Jana Kasprowicza praca magisterska (Instytut Bibliotekoznawstwa Uniwersytetu Wrocławskiego, 1976).

53) Kolaczkowski Julian ( 1837 Nowy Sącz - 21 IX 1889 Lwów)

inżynier kolejowy, historyk sztuki i przemysłu;

4 tys. wol. we Lwowie;

z zakresu archeologii, historii sztuki, literatury, ponadto 2 tys. rycin i 1360 autografów polskich;

po śmierci właściciela sprzedawane systematycznie;

Systematyczny katalog księgozbioru. J.Kolaczkowskiego we Lwowie. Stanisławów 1895. 
54) Komornicki Stefan Saturnin (29 XI 1887 w. Zawadka k. Kałusza 17 IV 1942 Kraków)

docent Uniwersytetu Jagiellońskiego, historyk sztuki, kustosz Muzeum xx Czartoryskich w Krakowie, muzeolog, autor prac z zakresu introligatorstwa;

ok. 5 tys. tomów, dołączony księgozbiór Mariana Sokołowskiego; głównie z zakresu historii sztuki;

zakupiony księgozbiór od spadkobierców w 1947 jest własnością Gabinetu Rycin Biblioteki PAN w Krakowie;

E.Chwalewik: Zbiory polskie. T. 1. Warszawa 1926, s. 251; A.Treiderowa: Zbiór graficzny Biblioteki PAN w Krakowie. „Rocznik Biblioleki PAN w Krakowie". Kraków 1956, s. 371.

\section{5) Konarski Michał (25 IX 1784 Słonim - 26 IV 1861 Odessa)}

nauczyciel, literat;

spory zbiór druków, 130 rękopisów, 37 wol. starych druków;

historia Polski XVI-XVIII w. i dzieje rodziny Potockich i Mniszków;

ofiarowane testamentem $1862 \mathrm{r}$. Bibliotece Towarzystwa Naukowego Krakowskiego, przejęte w 1873 r. przez Akademię Umiejętności (dzisiaj Bibliotekę PAN);

D.Rederowa, Z.Jabłoński: Zarys dziejów Biblioteki PAN w Krakowie w latach 1856-1956. „Rocznik Biblioteki PAN w Krakowie” 1955, s. 9, 15-16; B.Schnaydrowa: Fragment zbiorów tulczańskich $w$ rękopisach Biblioteki PAN w Krakowie. "Rocznik Biblioteki PAN w Krakowie" 1969, s. 69-102, bibliografia.

56) Kotwicz Władysław (20 III 1872 Ossowo k. Lidy - 3 X 1944 Czarny Bór pod Wilnem)

orientalista, mongolista, prof. Uniwersytetu Lwowskiego, członek Polskiego Towarzystwa Orientalistycznego;

3 tys. woluminów;

głównie ałtaistyka;

przekazane Uniwersytetowi Warszawskiemu, zaś archiwalia i numizmaty orientalne do Archiwum PAN w Krakowie;

M.Lewicki: Wladystaw Kotwicz. Rocznik Orientalistyczny 1950; Polski Slownik Biograficzny. T. 14, s. 508-509. 
57) Koziebrodzki Józef Marcin, Saba (1870 majątek Dźwiniaczka, Podole - 31 VII 1935 tamże)

kolekcjoner, ziemianin;

10 tys. tomów, rękopisy, inkunabuły, rękopisy, stare druki;

literatura piękna, historia, bibliografia, myślistwo, okultyzm, pamiętniki;

E.Chwalewik: Zbiory polskie. T. 1. Warszawa 1926, s. 424.

58) Kraszewski Józef Ignacy (28 VII 1812 Warszawa - 19 III 1887 Genewa)

powieściopisarz, publicysta, nakładca;

kilkanaście tysięcy tomów - w Dreźnie, stare druki, ponad 6 tys. rycin, 1950 rysunków;

polonica z XVI w., z zakresu historii sztuki, rękopisy, albumy;

rysunki i ryciny sprzedane w 1869 r. Bibliotece Branickich w Suchej, książki ofiarowane Bibliotece Jagiellońskiej, Akademii Umiejętności w Krakowie, Macierzy Szkolnej w Cieszynie i in.;

M.Rulikowski: Biblioteka Kraszewskiego. "Kurier Warszawski" 1908, nr 122; E.Skotniczny: Księgozhiór Józefa Ignacego Kraszewskiego - praca magisterska (Wyższa Szkoła Pedagogiczna w Krakowie, 1983); U.Ubrych: Studia nad księgozbiorem Kraszewskiego - praca magisterska (Instytut Bibliotekoznawstwa Uniwersytetu Wrocławskiego, 1979).

59) Krzyżanowski Stanisław Filip (12 V 1841 Petersburg - 31 III 1881 Warszawa)

archeolog, historyk, bibliograf;

11000 , w tym 6000 dzieł, 5000 rękopisów - z siedzibą w Czerpowodach, potem w Krakowie, Lwowie i Kijowie;

z różnych dziedzin wiedzy;

część w 1866 r. ofiarowana Bibliotece Towarzystwa Naukowego Krakowskiego, obecnie w Bibliotece PAN w Krakowie, kilkanaście rękopisów w Bibliotece Jagiellońskiej, trzy rękopisy w Bibliotece Narodowej;

K.Dziwik: Dzialalność naukowa i kolekcjonerska Stanislawa Filipa Krzyzanowskiego (18+1-I881). "Rocznik Biblioteki PAN w Krakowie" 1969 , s. 65-92, bibliografia. 
60) Lewicki Stanisław Rogala (1879 Lwów - 15 IV 1928 Warszawa)

właściciel księgarni, wypożyczalni książek, nakładca, założyciel i dyrektor Szkoły Handlowej we Lwowie, prof. Szkoły Nauk Politycznych w Warszawie;

16 tys. tomów w 1914 r. - z siedzibą we Lwowie;

z zakresu historii handlu i ekonomii, głównie dziejów handlu w Polsce;

przeszły w inne ręce;

S.Helsztyński: Przybyszewski. Wyd. 2. Kraków 1966 (rozdz. o Lewickim).

61) Lubomirski Andrzej (22 VII 1862 Przeworsk - 1953 w Ameryce Płd.)

ordynat przeworski, kurator Zakładu Narodowego im. Ossolińskich, poseł do Sejmu Galicyjskiego i członek Izby Panów w Wiedniu;

biblioteka w Przeworsku, odziedziczona po ojcu Jerzym Henryku Lubomirskim, licząca razem w 1944 r. ok. 20 tys. tomów i liczne czasopisma i in.;

$z$ różnych dziedzin wiedzy;

4517 wol. starych druków, 69 rękopisów, 429 muzykaliów, 20 map i atlasów, 4454 wol. druków XIX-XX w. i 4537 czasopism - wszystko to przekazane Bibliotece Jagiellońskiej a 10 tys. wol. przekazane Bibliotece Zakładu Narodowego im. Ossolińskich;

A.Peretiatkowicz, M.Sobieski: Wspólczesna kullura polska. Naukaliteratura-Sztuka. Życiorysy uczonych, literatów i artystów z wyszczególnieniem ich prac. Poznan 1932; S.Badeni: Andrzej Lubomirski. „Wiadomości" 1954, nr 18 (nekrolog).

\section{2) Lubomirski Henryk ( 15 IX 1777 - 20 X 1850 Drezno)}

pierwszy kurator Zakładu Narodowego im. Ossolińskich, ziemianin;

6 tys. tomów, umieszczonych w zorganizowanym przez siebie $\mathrm{Mu}$ zeum w Przeworsku k. Łańcuta (Biblioteka Przeworska), poszerzana;

z zakresu historii sztuki, literatury, botaniki $\mathrm{i}$ in;

odziedziczone przez syna Jerzego Henryka Lubomirskiego;

Biblioteka Ossolinskich: rps. 12352 I ('atalogue de musique vocale et instrumentale appartante... Thérèse l ubomirska née p-cesse ('zartoryski; Biblioteka Zakładu Narodowego im. Ossolińskich: rps. 12348/1 i 12349/II. 
63) Lubomirski Jerzy Henryk ( 28 V 1817 Wiedeń - 24 V 1872 Kraków) ordynat przeworski, polityk galicyjski, kurator Zakładu Narodowego im. Ossolińskich, współtwórca Akademii Umiejętności w Krakowie;

kilkanaście tysięcy tomów - z siedzibą w Przeworsku;

$\mathrm{z}$ różnych dziedzin wiedzy;

przekazana w 1871 r. część zbiorów Bibliotece Ossolińskich (7 432 dz., 465 map i atlasów);

Biblioteka Zakładu Narodowego im. Ossolińskich: rps. 12350/III; E.Krzyżek: Studia nad Bibliotekq Lubomirskich $w$ Przeworsku - praca magisterska (Instytut Bibliotekoznawstwa Uniwersytetu Wrocławskiego).

64) Lubomirski Stefan Andrzej ( 5 V 1862 - 1941)

ziemianin w majątku Kruszyna (k. Nowo-Radomska);

10 tys. wol. (w tym 4 tys. dz. polskich), odziedziczone po Władysławie Lubomirskim (1824-1882);

$\mathrm{z}$ wielu dziedzin wiedzy;

w 1912 r. przekazane Bibliotece Ossolineum, część przyrodnicza księgozbioru ofiarowana ok. 1919 r. Państwowemu Muzeum Przyrodniczemu w Warszawie;

E.Chwalewik: Zbiory polskie. T. 1. Warszawa 1926, s. 417; A.Fischer: Zaklad Narodowy im. Ossolinskich. Zarys dziejów. Lwów 1927, s. 82.

65) Lawrowski Jan ( 15 V 1773 w. Terka, Sanockie - 25 VI 1846 Przemyśl?)

ksiądz greckokatolicki, prof. uniwersytecki, członek Krakowskiego Towarzystwa Naukowego;

15000 tomów,

$\mathrm{z}$ wielu dziedzin, $\mathrm{z}$ teologii greckokatolickiej;

przed 1844 r. właściciel oddał 14139 książek i rękopisów przemyskiej kapitule greckokatolickiej;

A.T.Chłędowski: Spis dziel opuszczonych.. w Bentkowskiego „Historii literatury polskiej”. Lwów 1818, s. 175; A.Aleksiewicz: $Z$ dziejów drukarstwa przemyskiego w latach 1815-1860. "Roczniki Biblioteczne" 1977, z. 1-2, s. 225-226, 244. 
66) Lętowski Ludwik ( 13 lub 15 IX 1786 w. Tarnawatka k. Tomaszowa Lubelskiego - 25 VIII 1868 Kraków);

żołnierz wojsk polskich (1806-1816), ksiądz (od 1818), biskup (od 1845), pisarz, członek Towarzystwa Krakowskiego Naukowego;

1000 tomów i ponad 100 folialów rękopisów, herbarze, kroniki, druki unglerowskie, hallerowskie, dzieła dysydentów polskich XVI w.;

z zakresu historii, prawie kompletne piśmiennictwo historyczne z czasów Księstwa Warszawskiego, dzieła w języku polskim, francuskim i łacinie;

część sprzedana krewnemu Stanisławowi Jastrzębskiemu, pozostała zapisana w testamencie siostrzeńcowi Franciszkowi Ksaweremu Puszetowi, kilkanaście foliałów Bibliotece OO Dominikanów w Krakowie;

L.Łętowski: Wspomnienia pamiętnikarskie. Oprac. H.Barycz. Wyd.2. Wrocław 1956; J.Długosz: Kęlowski Ludwik. w: Slownik pracowników ksiazki polskiej. Warszawa 1972, s. 537.

67) Loś Ignacy (1790 - ok. 1850)

członek Stanów Galicyjskich, radca c.k. sądów szlacheckich we Lwowie, ziemianin;

1970 dz., 48 rękopisów, 51 map i atlasów we Lwowie;

wczesne druki krakowskie, kontytucje sejmowe od 1550 r., historia, prawo, teologia, literatura;

zakupione po śmierci właściciela przez S.Potockiego do biblioteki w Raju pod Brzeżanami, następnie do biblioteki Jakuba Potockiego z Helenowa, w końcu do Biblioteki Publicznej w Warszawie;

Biblioteka Ossolinskich: rps 6597 I Katalog biblioteki Ignacego kosia; W.Jabłonska: Inwentarze i katalogi biblioteczne $w$ zbiorach rękopiśmiennych Biblioteki Zakladu Narodowego im. Ossolinskich. „Ze skarbca kultury" 1969, z. 20, s. 137-138, D. Staniszewska-Gregor: Biblioteka Ignacego hrabiego tosia na podstawie katalogu - praca magisterska (Instytut Bibliotekoznawstwa Uniwersytetu Wrocławskiego).

68) Loziński Władysław (29 V 1843 w. Opary k. Drohobycza - 20 V 1913 Lwów)

pisarz, historyk kultury, redaktor;

znaczny zbiór książek (nieznana dokładna liczba tomów); $\mathrm{z}$ różnych dziedzin, głównie historii sztuki, muzeologii; 
część ofiarowana w 1914 r. Bibliotece przy Archiwum Akt Dawnych we Lwowie (późniejsza Biblioteka Miejska), część Bibliotece Uniwersytetu Lwowskiego;

Public:ne biblioteki lwowskie. Lwów 1926, s. 58-59.

69) Marszalkowicz Maksymilian (ok. 1806 - 26 VII 1878 w. Kamienica k. Limanowy);

uczestnik powstania 1846 r., ziemianin;

4 tys. dz. w tym ok. 10 tys. t. w majatku Kamienica, rękopisy z XVIIXVIII w., stare druki ( $w$ tym inkunabuły), komplet czasopism polskich;

z zakresu historii, literatury, prawa, polityki;

ofiarowane wraz z katalogiem w 1884 r. Bibliotece Akademii Umiejętności w Krakowie, część rozproszona (przypuszczalnie);

Rocznik Zarzadu Akademii Umiejęlności 1884, s, 18, 83; D.Rederowa, Z.Jabłoński: Zarys dziejów Biblioleki PAN w Krakowie. "Rocznik Bihlioleki P'AN w Krakowie" 1955, s. 58.

70) Mękicki Rudolf ( 8 IV 1887 - 21 VIII 1942)

muzykolog, numizmatyk, grafik, twórca ekslibrisów, nauczyciel rysunku w Seminarium Nauczycielskim we Lwowie, kustosz Muzeum Narodowego we Lwowie, dyrektor naukowy Muzeum Historycznego;

2 tys. pozycji (bez broszur), grafika, oprawy starych książek;

numizmatyka, heraldyka, muzealnictwo, pamiętniki, wydawnictwa ilustrowane, historia, sztuka;

przechowywane u wdowy, Julii Mękickiej w Gliwicach;

E.Chwalewik: Zbiory polskie. T. I. Warszawa 1926, s. 426; lincyklopedia Wiedzy o Ksiazce. Wrocław 1971, kol. 1517-1518.

71) Mieleszko-Maliszkiewicz Adam (1829 - listopad 1899 Żytomierz)

poeta;

3691 dz. w 6058 wol., w tym tylko 3290 wol. w języku polskim;

z zakresu historii powszechnej, historii Polski, filozofii, prawa, nauk matematyczno-przyrodniczych, ponadto czasopisma, kalendarze, powieści i poezja (2 251 wol.);

w 1881 r. sprzedane W.Branickiemu z Suchej, stąd nabyte w części przez Bibliotekę Jagiellońska;

E.Chwalewik: Zbiory polskie. T. 2. Warszawa 1927, s. 216-218; Biblioteka Ossolińskich: rps 74/64. Syis szczególowy dalel W. Branickiugon. k. 1-82. 
72) Mier Feliks Kazimierz Antoni, Prandota (30 VIII 1788 Warszawa 5 XII 1857 Lwów)

dyplomata;

wartościowa biblioteka, stare druki, mapy z całego świata, pierwsze wydania pisarzy zachodnio-europejskich;

$\mathrm{z}$ różnych dziedzin wiedzy;

odziedziczone przez syna Feliksa Wojciecha (8 VIII 1820 - 25 I 1870) właściciela Radziechowa (Galicja), przeszły do zbiorów S.H.Badeniego i rodziny Jędrzejowiczów (Galicja);

J.S.Dunin-Borkowski: Almanach blękitny. T. 1. Lwów 1908, s. 633; E.Chwalewik: Zbiory polskie. T. 2. Warszawa 1927, s. 208-209.

73) Morstin Ludwik (7 VIII 1782 w. Raciechowice k. Wiliczki - 18 XII 1865 Kraków)

wychowanek T.Czackiego, ziemianin;

duży księgozbiór po ojcu Janie (zm. 6 XII 1794), poszerzony nabytymi 700 księgami po staroście Fr.Dembińskim, kilkaset dzieł z XVI w. po Dobińskim i z biblioteki puławskiej Czartoryskich;

z zakresu historii, wojskowości i in.;

w części zniszczony w 1850 r. w czasie pożaru Krakowa, gdzie księgozbiór został umieszczony, dalsza część odziedziczona przez syna Władysława (1820-1880), przekazana z kolei córce Helenie (zm. 1917), następnie jej bratankowi Ludwikowi Hieronimowi (zm. 1966), który sprzedał w 1947-1949 Bibliotece Narodowej w Warszawie;

F.Radziszewski: Wiadomość historyczno-statystyczna o znakomitsych bibliotekach i archiwach publicznych i prywatnych. Kraków 1875, s. 32; Biblioteka Narodowa w latach 184-1956. Warszawa 1958, s. 31, 69; Biblioteka Narodowa: rps 7009, k. 35-37.

74) Moszyński Jerzy (24 IV 1847 Kraków - 24 I 1924 Wola Filipińska) pisarz, publicysta;

15012 wol., w tym 1331 tomów czasopism;

uzupełniony głównie dziełami polityczno-społecznymi i religijnymi; przekazane testamentem w 1923 r. Katolickiemu Uniwersytetowi w Lublinie, kolekcja rycin - nabyta w 1929 r. przez PAU w Krakowie;

Biblioteka Katolickiego Uniwersytetu Lubelskiego: rps 211 Księga inwentarzow'a glowna biblioteki Jerzego Moszyńskiego i Katalog rae- 
czowy biblioteki Jerzego Moszyńskiego - sporządzone przez Bronisława Jaworskiego (1852 - 1925)

75) Moszyński Piotr Stanisław Wojciech Alojzy (30 IV 1800 w. Łoniów, Sandomierskie - 18 VIII 1879 Kraków)

działacz polityczny i społeczny, zesłany na Syberię za udział w spisku dekabrystów;

liczne zbiory, pomnożone w 1855 r. o kilka tysięcy książek nabytych od Michała Wiszniewskiego i T.Żebrowskiego - w Krakowie (Lubicz);

z zakresu historii, literatury, druki polskie z XVI-XVII w., inkunabuły, bibliografia, czasopisma (ok. 200 tyt.);

po śmierci właściciela przejęte przez syna Jerzego Moszyńskiego;

Biblioteka Jagiellońska: rps 9066 Ksiq̇ka do wpisywania ksiqżek wypozyczonych z biblioteki Piotra Moszyńskiego.

76) Muczkowski Józef ( 1795 Maszki - 31 VII 1858 Kraków)

filolog, bibliotekarz, kustosz Biblioteki Jagiellońskiej, profesor bibliografii na Uniwersytecie Jagiellońskim;

2 tys. dzieł;

głównie druki polskie;

uległy częściowemu zniszczeniu;

K.Kieć: U schylku III-go stulecia Drukarni (Iniwersytetu Jagiellońskiego. Kraków 1969, s. 6.

77) Münnich Józef (21 XII 1880 Kraków - 6 IV 1939 tamże), wnuk Józefa Edwarda Friedleina

księgarz, nakładca, antykwariusz;

10 tys. tomów przejęte od J.E.Friedleina;

z zakresu geologii, paleontologii, przyrody i in.;

właściciel sprzedał różnym bibliotekom m.in. Bibliotece PAU, przekazał część bratu Edwardowi Münnichowi (17 VII 1882 - 25 I 1965);

E.Chwalewik: Zhiory polskie. T. 1. Warszawa 1926, s. 254; Biblioteka Ossolińskich: rpsy 12'/35 III - 12737 III.

78) Olekliński Stanisław (XIX w.)

2 tys. dzieł, ryciny polskie;

teoria i historia sztuki; 
E.Chwalewik: Zbiory polskie. T. 1. Warszawa 1926, s. 426.

79) Ostaszewski-Barański Kazimierz (11 I 1862 Jeziorna - 1913 Lwów) dziennikarz, pisarz historyczny;

2 tys. tomów;

historia, leopolitana;

E.Chwalewik: Zbiory polskie. T. 1. Warszawa 1926, s. 426; Polski Slownik Biograficzny. T. 24, s. 461-462.

80) Opalek Mieczysław (9 IX 1881 Lwów - 6 V 1964 Nowy Sącz)

nauczyciel, literat, dziennikarz, działacz, bibliofil, archiwista;

5 tys. tomów w 1930 r.;

głównie literatura piękna, historia (galicjana i leopolitana), historia literatury, oświaty i kultury, druki bibliofilskie;

po II wojnie światowej uległy rozproszeniu, część znalazła się w Bibliotece Ossolineum (2 209 jednostek grafiki), niektóre partie książek trafiły do Biblioteki Uniwersytetu we Wrocławiu, Warszawie i Katolickiego Uniwersytetu Lubelskiego;

S.J.Gruczyński: Michal Opalek (1881-1964). Szkic bio-bibliograficzny. "Roczniki Biblioteczne" 1966, s. 183-220.

81) Pauli Ignacy Żegota (1 VII 1814 Nowy Sacz - 20 X 1895 Kraków)

historyk, etnograf, bibliotekarz, bibliograf, współpracownik K.J.Turowskiego w jego „Bibliotece Polskiej”;

7000 tomów, rękopisy, mapy;

polonica z XV-XVII w.;

zapisane bonifratrom na rozbudowę szpitala w Krakowie, zakupione od nich w 1898 r. przez A.Ponińskiego do Horyńca, skąd przeszły do Biblioteki Narodowej w Warszawie, rękopisy i mapy darowane W.Wisłockiemu, a ten Bibliotece Jagiellońskiej;

Przewodnik Bibliograficzny. Pod red. W.Wisłockiego. 1887, s. 140$141 ; 1895$, s. 189 ; 1896, s. 99, 169, 209; 1897, s. 121, 160-161; 1898, s. 198; H.Lipska: Zegota Pauli (w 40-lecie śmierci). „Przeglad Bibliotecany" 1936, s. 1-16; J.Przygocka: Zegota Pauli - zapomniany bibliotekarz i bibliograf. „Roczniki Biblioteczne”: 1970, s. 725-771. 
82) Pawlikowski Gwalbert Józef (12 VII 1793 Przemyśl - 30 I 1852 Lwów)

pisarz, z-ca dyrektora (1834-1839) i Kuratora (1834-1847) Zakładu Narodowego im. Ossolińskich, ziemianin w majątku Medyka k. Przemyśla;

$16520 \mathrm{dz}$. w ok. 20 tys. tomów, w tym polonica 13900 tomów, ponad 24 tys. pozycji grafiki z siedzibą w Medyce, po 1849 r. we Lwowie;

$\mathrm{z}$ różnych dziedzin wiedzy;

przekazane synowi Mieczysławowi Gwalbertowi Pawlikowskiemu;

M.Gębarowicz: Katalog rękopisów Biblioteki im. Gwalberta Pawlikowskiego. Lwów 1929.

83) Pawlikowski Jan Gwalbert Aleksander Józef (18 III 1860 Medyka 5 III 1939 Lwów)

ekonomista, prof. w Akademii Rolniczej w Dublanach, na Wydziale Rolnictwa Uniwersytetu Jagiellońskiego, ziemianin;

duża biblioteka odziedziczona po ojcu Mieczysławie Gwalbercie Henryku Pawlikowskim - licząca 21503 dz. w 26 tys. tomów, 271 rękopisów, 4270 autografów, mapy, zbiory graficzne;

$\mathrm{z}$ różnych dziedzin wiedzy;

ofiarowane w 1921 r. jako wieczysty depozyt Bibliotece Ossolineum we Lwowie;

A.Fischer: Zaklad Narodowy imienia Ossolinskich. Zarys dziejów. Lwów 1927, s. 41-42, 103-104; T.Mańkowski: Dzieje zbiorów graficznych Zakladu Narodowego im. Ossolińskich. „Rocznik Zakladu Narodowego im. Ossolińskich" 1957, s. 90-99; M.Grońska, M.Ochońska: Zbiory Pawlikowskich. Katalog. Wrocław 1960, s. 5-11.

84) Pawlikowski Mieczysław Gwalbert Henryk (9 IX 1834 Lwów 23 XII 1903 Kraków)

pisarz, publicysta, zastępca Komisarza Rządu Narodowego na Galicję Wschodnia, ziemianin;

biblioteka odziedziczona po ojcu Gwalbercie Józefie Pawlikowskim, powiększona znacznie;

z różnych dziedzin wiedzy;

przekazane synowi Janowi Gwalbertowi Aleksandrowi Józefowi Pawlikowskiemu; 
E.Chwalewik: Zbiory polskie. T. 1. Warszawa 1926, s. 386; B. Bogusławska: Dzieje bibliotek Pawlikowskich do roku 1921 - praca magisterska (Instytut Bibliotekoznawstwa Uniwersytetu Wrocławskiego).

85) Piątkowski Wincenty (1795 Wiśnicz, Krakowskie - 18 II 1870 w. Wielkozagórze k. Miechowa)

urzędnik, naczelnik powiatu miechowskiego, gubernator cywilny radomski;

10 tys. tomów - z siedzibą w Miechowie;

z zakresu historii i literatury polskiej;

zniszczone w czasie rabunku i pożaru miasta Miechowa po bitwie 17 II $1863 \mathrm{r}$;

F.Radziszewski: Wiadomość historyczno-statystyczna o znakomitszych bibliotekach i archiwach public znych i prywatnych. Kraków 1875, s. 48 .

86) Podolecki Jan Kanty (1800 Bezmiechowa lub Bezmichowa w Sanockiem - $28 \mathrm{~V} 1855 \mathrm{Pau}$ )

literat, pisarz historyczny, działacz rewolucyjny, członek Towarzystwa Demokratycznego;

$487 \mathrm{dz}$. w ponad 1000 tomów, w tym rękopisy;

$\mathrm{z}$ różnych dziedzin, głównie teologii, prawa, polityki, fïlozofii i in.;

Biblioteka Zakładu Narodowego im. Ossolińskich: rps 1019/I Katalog biblioteki Wincentego i.Jana Kantego Podoleckich w Reepedzi.

87) Polkowski Ignacy (4 III 1833 w. Zduny, Mazowsze - 27 VIII 1888 Kraków)

ksiądz, historyk, archiwista od 1878 r. w Kapitule krakowskiej, bibliotekarz tej Kapituły;

9679 dz. w 16529 tomach, w tym 49 inkunabułów;

$z$ różnych dziedzin wiedzy, zbiór kopernikianów;

zakupione (prócz rękopisów i kilku inkunabułów przekazanych testamentem Bibliotece Seminarium Duchownego w Warszawie) przez A.Ponińskiego na licytacji w Krakowie w 1895 r., kopernikiana znalazły się w Muzeum Kopernika w Rzymie;

S.Ptaszycki: lincyklopedia nauk pomocniczych historii i literatury polskiej. Lublin 1921, s. 44, 76, 84-85, 246; A.Kawecka-Gryczowa, K.Piekarski: Katalog Bihlioleki Horynteckiej. Cz. 1. Warszawa 1936. 
88) Poniński Aleksander Oskar Franciszek (26 II 1856 - 1910)

prawnik, polityk, poseł do Rady Państwa w Wiedniu, ziemianin w majątku rodzinnym Horyńcu (Lwowskie);

40 tys. tomów (biblioteka horyniecka), rękopisy, inkunabuły, druki XVI-XVIII w.;

$\mathrm{z}$ różnych dziedzin wiedzy, w tym m.in. literatura balneologiczna, teatralia;

zniszczone znacznie w czasie I wojny światowej, ofiarowane Bibliotece Narodowej w Warszawie (Biblioteka Horyniecka XX. Ponińskich), spalone w czasie Powstania Warszawskiego;

E.Chwalewik: Zhiory polskie. T. 1. Warszawa 1926, s. 124-125, T. 2. Warszawa 1927, s. 229; K.Piekarski: Katalog Biblioteki Horynieckiej ks. Ponińskich. (.z.1. Inkunabuly i polonica XVI wieku. Warszawa 1936.

89) Potocki Alfred Józef (1817 Łańcut - 18 V 1889 Paryż)

namiestnik Galicji, ziemianin;

duża biblioteka w Łańcucie, odziedziczona po Alfredzie Potockim, poszerzona zbiorami przyrodniczymi nabytymi od Reicherta $i$ in.;

z różnych dziedzin wiedzy;

odziedziczone przez następnych ordynatów, poszerzone w $1923 \mathrm{r}$. o część księgozbioru biblioteki tulczyńskiej - odziedziczone po M.Potockim (1845-1917), wywiezione w 1944 r. w części przez Alfreda Potockiego poza granice, reszta w latach 1948-1949 upaństwowiona ( 13 tys. druków, i in.);

J.Rudnicka: Biblioteka w palacu lańcuckim. "Przegiad Humanistyczny" 1958, nr 2, s. 186-190.

90) Potocki Alfred (1784 - 23 XII 1862 Lańcut)

organizator ordynacji łańcuckiej, ziemianin;

biblioteka w Łańcucie odziedziczona po dziadkach - Stanisławie Lubomirskim (1719-1783) i jego żonie Elżbiecie (1733-1816);

$z$ różnych dziedzin wiedzy;

odziedziczone przez Alfreda Józefa Potockiego;

E.Chwalewik: Zhiory polskie. T. 1. Warszawa 1926, s. 430-431.

91) Potocki Artur (14 VI 1850 Krzeszowice - 26 II 1890 tamże)

poseł na sejm krajowy, ziemianin;

spora biblioteka odziedziczona po ojcu Adamie w Krzeszowicach, który z kolei odziedziczył po swym ojcu Arturze (27 V 1787 - 30 I 1832). 
połączona $\mathrm{z}$ resztkami biblioteki Potockich z Zatora, po śmierci właściciela przeszła pod opiekę Krystyny z Tyszkiewiczów, która ulokowała w pałacu ,Pod Baranami" w Krakowie;

$\mathrm{z}$ różnych dziedzin wiedzy, rękopisy, numizmaty, archiwalia;

zdekompletowane zbiory w okresie okupacji hitlerowskiej przekazane w 1947 r. jako depozyt Bibliotece Jagiellońskiej ( 3500 dzieł w ok. 6700 wol.), ok. 3540 otrzymała Biblioteka Narodowa;

L.Dębicki, S.Tarnowski: Artur Potocki. Kraków 1890; E.Chwalewik: Zbiory polskie. T. 1. Warszawa 1926, s. 255-256, T.2. Warszawa 1927, s. 460-461; F.Radziszewski: Wiadomość historyczno-statystyczna o znakomitszych bibliotekach i archiwach publicznych i prywatnych. Kraków 1875 , s. 32-33, 121-122.

\section{2) Przybysławski Kazimierz (ur. ok. 1860)}

właściciel majątku w Uniżu, ziemianin;

zbiory odziedziczone po ojcu Władysławie Przybysławskim, powiększone zakupami m.in. druków z XVII w. - 6 tys. tomów (1926);

$\mathrm{z}$ różnych dziedzin wiedzy;

w czasie I wojny światowej losy zbiorów nieznane;

A.Czołowski: Zniszczenia wojenne bibliotek małopolskich. w: Pamiętnik Trzeciego Zjazdu Bibliofilów Polskich we Lwowie... Lwów 1929, s. 86,89 .

\section{3) Przybyslawski Wladyslaw (1830 - 1 II 1908 Lwów)}

konserwator zabytków przedhistorycznych, członek Komisji Archeologicznej Akademii Umiejętności, ziemianin;

odziedziczone zbiory po ojcu Andrzeju Przybysławskim właścicielu Uniża nad Dniestrem (k. Buczacza), wzbogacone zakupami innych bibliotek (np. Józefa Puzyny) - kilka tysięcy tomów - z siedzibą we Lwowie;

$\mathrm{z}$ różnych dziedzin wiedzy;

przekazane synowi Kazimierzowi Przybysławskiemu;

Zbiory w Unizu. „Na Ziemi Naszej” 1909, nr 13; E.Chwalewik: Zbiory polskie. T. 1. Warszawa 1926, s. 427; T. 2. Warszawa 1927, s. 264-265.

94) Rastawiecki Edward ( 2 X 1805 r. w. Nowosiółki, k. Tomaszowa Lubelskiego - 23 II 1874 Warszawa)

kolekcjoner, radca Towarzystwa Kredytowego Ziemskiego, redaktor; 
10000 tomów;

polonica w języku angielskim, francuskim i niemieckim dotyczące powstań, komplet czasopism polskich, mapy i atlasy;

w 1869 r. część ofiarowana Katedrze Archeologii Uniwersytetu Jagiellońskiego, reszta sprzedana w 1870 r. S.Mielżyńskiemu;

95) Romer Eugeniusz (3 II 1871 Lwów - 28 I 1954 Kraków)

geograf, kartograf, bibliograf, prof. Uniwersytetu Lwowskiego, twórca Biblioteki Instytutu Kartograficznego, współzałożyciel wydawnictwa „Atlas";

15 tys. tomów, 20 tys. map;

geografia, unikalne mapy;

w części znajduje się w Instytucie Geograficznym Uniwersytetu Wrocławskiego, reszta rozproszona;

Encyklopedia Wiedzy o Ksiazce. Wrocław 1971, kol. 2099.

96) Ryszard Antoni - pseudonim, nazwisko: Antoni Ryszard Zaczyński (22 V 1841 Szczebrzeszyn k. Zamościa - 12 I 1894 Kraków)

numizmatyk, bibliograf, handlowiec, członek Towarzystwa Numizmatycznego w Krakowie;

998 poz. (m.in. białe kruki);

$\mathrm{z}$ zakresu mennictwa, medalierstwa historycznego i dewocyjnego;

po śmierci właściciela zbiory nabyte przez F.Biesiadeckiego i przekazane do Biblioteki Czapskich w Krakowie;

Spis dziel numizmatycznych polskich $i=$ nimi stycznośc majacych, zebranych przez Antoniego Ryszarda 1870-1893. Kraków 1894; J.Bohdan: Rękopisy numizmatyczne Antoniego Ryszarda w Bibliotece Ossolińskich. „Wiadomości Numizmatyczno-Archeologiczne” 1917, nr 2.

97) Sanguszko Roman Stanislaw Adam (24 IV 1800 w. Antoniny, Wołyń - 26 IIl 1881 Sławuta, Wołyń)

powstaniec (1831), zesłaniec, ziemianin;

5 tys. tomów - z siedzibą w Sławucie, w tym biblie z XVI w., kroniki polskie, rękopisy;

z różnych dziedzin wiedzy, głównie historii i religii;

odziedziczone przez bratanka Romana Damiana Eustachego Pawła Sanguszkę; 
J.T.Stecki: Spis rękopisów biblioteki slawuckiej. w: Wolyń. T. 1. Lwów 1864, s. 357-360.

98) Sanguszko Roman Damian Eustachy Paweł (17 III 1832 Przeworsk

- 1 XI 1917 Sławuta)

założyciel ordynacji sławuckiej;

odziedziczona biblioteka po stryju i powiększona - 25 tys. tomów (1908 r.);

$z$ różnych dziedzin wiedzy;

częśc zbiorów w 1915 r. ulokowana w Gumniskach k. Tarnowa, pozostałe zniszczone w $1917 \mathrm{r}$;

Z.Radzimiński: Roman Sanguszko. Lwów 1918; E.Ryszczewska: Mord stawucki. Lwów 1919.

99) Sanguszkowa Klementyna Maria Teresa z d. Czartoryskich (30 IX 1780 - 2 III 1852 Sławuta, Wołyń)

założycielka biblioteki, ziemianka;

2400 wol., w tym 1900 wol. wydawnictw francuskich i 500 wol. polskich, powiększone przez następców (syna, wnuka $\mathrm{i}$ in.) do 12 tys. tomów (1875 r.), 18790 wol. (1945);

z. zakresu literatury pięknej, historii, geografii, nauk ścisłych;

przejęte w 1945 przez Bibliotekę Muzeum Ziemi Tarnowskiej, podzielone w 1947 r.: stare druki i rękopisy dla Biblioteki Jagiellońskiej, książki polskie nowsze dla Biblioteki Uniwersytetu we Wrocławiu, archiwum rodzinne Sanguszków umieszczone w Archiwum Państwowym w Krakowie;

A.Żak: Zbiory Sanguszków w Wojewódzkiej Bibliotece Public nej im. Juliusza Slowackiego w Tarnowie - praca magisterska (Wyższa Szkoła Pedagogiczna w Krakowie, 1979).

100) Sapieha Adam Stanisław (4 XII 1828 Warszawa - 20 VII 1903 Reichenhall, Bawaria)

zbieracz książek, ziemianin;

10 tys. dz. w ok. 15 tys. tomów, w tym stare druki, mapy, ryciny odziedziczone po ojcu Leonie Sapieże (1802-1878) - z siedzibą w Krasiczynie k. Przemyśla;

$z$ różnych dziedzin wiedzy;

dziedziczone do 1939 r. przez Andrzeja Sapiehę;

S.Kieniewicz: Adam Sapieha (1828-1903). Lwów 1939. 
101) Sauczy Tadeusz (XIX w.)

1000 tomów;

historia w tym szczególnie Powstanie Styczniowe 1863 r.;

podarowane Bibliotece Miejskiej we Lwowie;

E.Chwalewik: Zbiory polskie. T. 1. Warszawa 1926, s. 381.

102) Semkowicz Aleksander ( 17 VI 1885 Tłuste pow. Zaleszczyki 8 VII 1954 Warszawa)

introligator, bibliograf, dyrektor Muzeum im. A.Mickiewicza w Warszawie;

4000 tomów, czasopisma emigracyjne współczesne Mickiewiczowi;

literatura, w tym mickiewicziana;

ofiarowane Bibliotece Jagiellońskiej, lecz stały się podstawą Biblioteki Muzeum im. A.Mickiewicza w Warszawie;

E.Chwalewik: Zhiory polskie. T. 1. Warszawa 1926, s. 428; Encyklopedia Wiedzyo Ksiatce. Wrocław 1971, kol. 2145.

103) Schindler Jan (3 IX 1802 Stanisławów - 4 IV 1890 Kraków)

ksiądz, prof. Uniwersytetu Jagiellońskiego;

$7437 \mathrm{dz}$. (w 10075 tomach);

z zakresu języków zachodnich, historii, mapy, ryciny, rękopisy;

zapisane Bibliotece Jagiellonskiej;

W.Kopff: Wspomnienia z ostatnich lat Rzeczypospolitej Krakowskiej. Kraków 1906, s. 26, 31 , 47, 98; Sprawozdanie... Uniwersytetu .Jagiellonskiego. Kraków 1890, s. 10, 12.

104) Sierakowski Waclaw (1740 - 24 II 1806 Kraków)

hrabia, ksiądz, proboszcz w Sandomierzu, od 1797 kanonik i proboszcz katedry w Krakowie;

159 dz. w 1257 tyt.;

z zakresu religii, historii, literatury, muzyki, prawa, ekonomii, matematyki, wojskowości i medycyny;

przekazane w testamencie przyjacielowi ks. M.W.Dubieckiemu, po śmierci którego zbiory uległy rozproszeniu;

J.Wiśniewski: Katalog pralatów i kanoników sandomierskich. Radom 1928. 
105) Sierakowski Sebastian (9 I 1743 - 9 VIII 1824 Kraków)

prałat i proboszcz katedry krakowskiej, rektor Szkoły Głównej Krakowskiej, współpracownik Komisji Edukacji Narodowej, brat Wacława Sierakowskiego;

1500 dzieł;

z zakresu teologii, historii, architektury, geometrii, fizyki i podróżnictwa;

przekazane testamentem w 1821 r. Bibliotece Uniwersytetu Jagiellońskiego ( 1309 cennych książek i zbiór sztychów);

Biblioteka Jagiellońska: rpsy 1874, 4176.

106) Smaglowski Wincenty, Nowina (26 VII 1806 Brody - 10 I 1883 Stanisławów)

nauczyciel domowy, bibliotekarz;

duży księgozbiór, w tym bogaty zbiór kartograficzny, pism emigracyjnych, stare druki polskie, literatura zagraniczna dotycząca Polski;

głównie z zakresu historii i archeologii;

ofiarowany Bibliotece Miejskiej w Stanisławowie jako jej podstawowa część księgozbioru;

N.N.: Biblioteka Miejska w Stanislawowie (akt fundacyjny). „Kronika Stanislawowa" 1885, nr 8-9.

\section{7) Smetański Jan (6 VII 1881 Hołyń - 16 VI 1959 Przemyśl)}

nauczyciel, członek Towarzystwa Miłośników Książki we Lwowie; 40 tys. tomów;

z zakresu różnych dziedzin wiedzy, głównie przyrodoznawstwa;

część zakupiona przez Instytut Zoologii Polskiej Akademii Nauk w Warszawie i Bibliotekę Śląską, reszta w posiadaniu rodziny;

J.Mayer: Smetański Jan. W: Slownik pracowników ksiażki polskiej. Warszawa 1972, s. 832-833.

108) Smoniewski Jan Wincenty (15 III 1793 w. Smoniewo, Podlasie 25 XII 1967 Kraków)

nauczyciel, członek Towarzystwa Naukowego Krakowskiego od 1858;

980 tomów, pieczęcie, ryciny, mapy, pergaminy;

z zakresu historii i literatury pięknej (w języku polskim i obcych), religii, geografii, prawa, przyrody i rolnictwa;

podarowany Towarzystwu Naukowemu Krakowskiemu; 
Biblioteka Polskiej Akademii Nauk w Krakowie: rps 504 Spis księgozbioru J.W.Smoniewskiego z r. 1854.

109) Soltys Tadeusz (XIX w.)

2 tys. tomów;

historia, literatura, sztuka;

część zbiorów podarowana Bibliotece Miejskiej we Lwowie;

E.Chwalewik: Zbiory polskie. T. 1. Warszawa 1926, s. 381, 428.

110) Speiser Anzelm (ok. 1755 Distalhausen k. Würzburga - 1 XII 1807 Kraków)

ksiądz, cenzor, bibliotekarz Biblioteki Jagiellońskiej;

7677 wol. w tym 913 starych druków i 2403 dzieł;

z zakresu głównie historii;

zapisane bratu Danielowi, nabyte potem przez min. F.Łubieńskiego dla Biblioteki Sądu Apelacyjnego w Warszawie, w 1817 r. Bibliotece Uniwersytetu Warszawskiego;

W.Stummer: Biblioteka Sadu Apelacyjnego w Warszawie 1810-1865. „Roczniki Biblioteczne” 1958, s. 437.

111) Stadnicki Aleksander (27 II 1806 w. Cieklin k. Jasła - 19 XII 1861 Lwów)

prawnik;

księgozbiór odziedziczony w Dukli;

nabyty w 1855 r. przez W.Baworowskiego we Lwowie, rękopisy przekazane Bibliotece Ossolineum;

W.Kętrzyński: Zakład Narodowy im. Ossolińskich. Lwów 1894, s. 58; A.Fischer: Zaklad Narodowy imienia Ossolińskich. Zarys dziejów. Lwów 1827 , s. 80.

112) Stadnicki Antoni (1771 w. Opatów, Sieradzkie - sierpień 1836 w Trzcińcu k. Jasła)

historyk, członek Towarzystwa Naukowego Krakowskiego, ziemianin;

kilka tys. dzieł, stare druki, polonica, slavica, rękopisy w swych majątkach Żmigród i Dukla k. Jasła; 
105) Sierakowski Sebastian (9 I 1743 - 9 VIII 1824 Kraków)

prałat i proboszcz katedry krakowskiej, rektor Szkoły Głównej Krakowskiej, współpracownik Komisji Edukacji Narodowej, brat Wacława Sierakowskiego;

1500 dzieł;

z zakresu teologii, historii, architektury, geometrii, fizyki i podróżnictwa;

przekazane testamentem w 1821 r. Bibliotece Uniwersytetu Jagiellońskiego (1 309 cennych książek i zbiór sztychów);

Biblioteka Jagiellońska: rpsy 1874, 4176.

106) Smaglowski Wincenty, Nowina (26 VII 1806 Brody - 10 I 1883 Stanisławów)

nauczyciel domowy, bibliotekarz;

duży księgozbiór, w tym bogaty zbiór kartograficzny, pism emigracyjnych, stare druki polskie, literatura zagraniczna dotycząca Polski;

głównie $\mathrm{z}$ zakresu historii i archeologii;

ofiarowany Bibliotece Miejskiej w Stanisławowie jako jej podstawowa część księgozbioru;

N.N.: Biblioteka Miejska w Stanistawowie (akt fundacyjny). „Kronika Stanislawowa" 1885, nr 8-9.

107) Smetański Jan (6 VII 1881 Hołyń - 16 VI 1959 Przemyśl)

nauczyciel, członek Towarzystwa Miłośników Książki we Lwowie;

40 tys. tomów;

z zakresu różnych dziedzin wiedzy, głównie przyrodoznawstwa;

część zakupiona przez Instytut Zoologii Polskiej Akademii Nauk w Warszawie i Bibliotekę Śląska, reszta w posiadaniu rodziny;

J.Mayer: Smetański Jun. W: Slownik pracowników ksiqżki polskiej. Warszawa 1972, s. 832-833.

108) Smoniewski Jan Wincenty (15 III 1793 w. Smoniewo, Podlasie 25 XII 1967 Kraków)

od 1858;

nauczyciel, członek Towarzystwa Naukowego Krakowskiego

980 tomów, pieczęcie, ryciny, mapy, pergaminy;

z zakresu historii i literatury pięknej (w języku polskim i obcych), religii, geografii, prawa, przyrody i rolnictwa;

podarowany Towarzystwu Naukowemu Krakowskiemu; 
Biblioteka Polskiej Akademii Nauk w Krakowie: rps 504 Spis księgozbioru J.W.Smoniewskiego z r. 1854.

109) Soltys Tadeusz (XIX w.)

2 tys. tomów;

historia, literatura, sztuka;

część zbiorów podarowana Bibliotece Miejskiej we Lwowie;

E.Chwalewik: Zbiory polskie. T. 1. Warszawa 1926, s. 381, 428.

110) Speiser Anzelm (ok. 1755 Distalhausen k. Würzburga - 1 XII 1807 Kraków)

ksiądz, cenzor, bibliotekarz Biblioteki Jagiellońskiej;

7677 wol. w tym 913 starych druków i 2403 dzieł;

z zakresu głównie historii;

zapisane bratu Danielowi, nabyte potem przez min. F.Lubieńskiego dla Biblioteki Sądu Apelacyjnego w Warszawie, w 1817 r. Bibliotece Uniwersytetu Warszawskiego;

W.Stummer: Biblioteka Sąu Apelacyjnego w Warszawie 1810-1865. „Roczniki Biblioteczne” 1958, s. 437.

111) Stadnicki Aleksander (27 II 1806 w. Cieklin k. Jasła - 19 XII 1861 Lwów)

prawnik;

księgozbiór odziedziczony w Dukli;

nabyty w 1855 r. przez W.Baworowskiego we Lwowie, rękopisy przekazane Bibliotece Ossolineum;

W.Kętrzyński: Zakład Narodowy im. Ossolińskich. Lwów 1894, s. 58; A.Fischer: Zakład Narodowy imienia Ossolinskich. Zarys dziejów. Lwów 1827, s. 80 .

112) Stadnicki Antoni (1771 w. Opatów, Sieradzkie - sierpień 1836 w Trzcińcu k. Jasła) nin;

historyk, członek Towarzystwa Naukowego Krakowskiego, ziemia-

kilka tys. dzieł, stare druki, polonica, slavica, rękopisy w swych majątkach Żmigród i Dukla k. Jasła; 
z zakresu historii i filozofii z XVIII-XIX w., księgozbiór w Dukli powiększono zakupem części zbiorów J.Kuropatnickiego;

odziedziczone przez synów Kazimierza i Aleksandra Stadnickiego;

Spis map i sztychów z biblioteki Antoniego Stadnickiego w Zmigro. dzie - zachowany $w$ rękopisach Biblioteki Zakładu Narodowego im. Ossolińskich; W.Jabłońska: Inwentarze i katalogi biblioteczne $w$ zbiorach rękopiśmiennych... "Ze skarbca kultury" 1969, z. 20, s. 150151 .

113) Stadnicki Kazimierz (1808 w. Żmigród - 9 IV 1886 Lwów) prawnik, historyk, radca Namiestnictwa we Lwowie; księgozbiór w Żmigrodzie powiększył trzykrotnie; $\mathrm{z}$ różnych dziedzin wiedzy, głównie historii, prawa; ofiarowane niektóre pozycje Bibliotece Ossolineum we Lwowie; "Wiadomości Bibliograficzne Warszawskie" 1886, s. 79; "Czasopismo Naukowe Zakladu Narodowego im. Ossolińskich" 1863; t. 3, s. $377 ; 1865$, t. 7 , s. $415 ; 1866$, t. 8 , s. $384,386,389,396,399,405$ (Spis druków Kazimierza Stadnickiego).

114) Starża Wronowski Stanisław (1733 - 1839)

radca c.k. Trybunału Szlacheckiego we Lwowie, ziemianin;

30000 tomów, w tym inkunabuły, ponadto rękopisy, obrazy królów, stare druki;

z różnych dziedzin wiedzy;

6671 druków polskich i obcych (inkunabuły, stare druki, rękopisy) przekazanych w 1838 r. Bibliotece Zakładu Narodowego im. Ossolińskich, inne uległy rozproszeniu;

Czasopism ksieggozbioru publiczne im. Ossolińskich. 1828, z. 2, s. 166; tamże: 1829, z. 4, s. 133; I.Lubieniecka: Księgozbiór Stanislawa Starzy Wronowskiego (1733-1839) we Lwowie - praca magisterska (Instytut Bibliotekoznawstwa Uniwersytetu Wrocławskiego).

115) Strzelbicki Marcin(ok. 1801 - 20 IV 1871 Kraków) dr praw, notariusz Wielkiego Księstwa Krakowskiego; $6000 \mathrm{dz}$;

z zakresu historii i prawa polskiego, rękopisy;

nabyte zostały po śmierci właściciela przez J.E.Friedleina; 
116) Szaniawski Józef Kalasanty (1764 Kalwaria Zebrzydowska - 16 V 1843 Lwów)

filozof, prawnik, działacz polityczny, prezes Towarzystwa do Ksiag Elementarnych, kierownik Wydziału Cenzury w Królestwie (1822-1830);

duży księgozbiór domowy, ok. 7000 tomów, w tym inkunabuły, druki z XVI w., atlasy, sztychy;

z zakresu filozofii, historii, prawa, ekonomii, estetyki, medycyny, wychowania, encyklopedie i słowniki;

część przekazana jako tymczasowy depozyt Bibliotece Warszawskiego Muzeum Przyjemności i Użytecznej Zabawy, 3000 tomów ofiarowane jezuitom we Lwowie (włączone do jezuickiej Biblioteki Prowincji Małopolskiej w Krakowie) - Inwentarz ksiqzek J.K.Szaniawskiego; 3980t. zakupione do Biblioteki Rządowej (znajdują się w Bibliotece Uniwersyteckiej w Warszawie) i in.;

S.Bednarski: Biblioteka J.K.Szaniawskiego. Kraków 1929.

117) Szembek Jerzy Józef (1851 w. Ujście, Podole - 7 VIII 1905 Poręba)

ksiądz od 1893, biskup płocki od 1901, arcybiskup mohylewski od 1903;

odziedziczona biblioteka w Porębie i cenny księgozbiór w Saratowie; księgozbiór w Saratowie to zbiór druków religijnych z w. XVI-XVIII;

częściowo zdewastowana w czasie II wojny światowej przez hitlerowców i wywieziona na Śląsk, po wojnie zabezpieczona przez Zbiornicę Księgozbiorów Zabezpieczonych w Bytomiu, przekazana Bibliotece Śląskiej;

J.Berger-Mayerowa: () bibliotece Szembeków. „Sprawozdanie Wroclawskiego Towarzystwa Naukowego". Seria A 1956, s. 56-57.

\section{8) Szembek Józef (1780-1874)}

kapitan wojsk napoleońskich, sędzia pokoju Rzeczypospolitej Krakowskiej, ziemianin;

10 tys. tomów w majątku Poręba k. Krakowa, powiększona o księgozbiór J.Muczkowskiego (2 000 t.);

$\mathrm{z}$ różnych dziedzin wiedzy, pierwsze wydania klasyków polskich, zbiór autografów biskupów polskich od XVII w;

częściowo spalone podczas pożaru w lutym 1868 r., odziedziczone przez Jerzego Józefa Szembeka; 
M.Offmański: Nad starymi drukami z biblioteki Józefa Szembeka. „Biblioteka Warszawska” 1901 III, s. 156-167; F.Radziszewski: Wiadomość historyczno-statystyczna o znakomitszych bibliotekach $i$ archiwach publicznych i prywatnych. Kraków 1875, s. 63.

\section{9) Szujski Józef (16 VI 1835 Tarnów - 7 II 1883 Kraków)}

historyk, literat, prof. i rektor Uniwersytetu Jagiellońskiego;

3939 dz.;

z zakresu literatury pięknej, historii, religii, językoznawstwa, prawa, polityki, oświaty i in.;

po śmierci właściciela przejęty przez syna Władysława Szujskiego, w 1891 r. scedowany w większości na Nowy Sącz (obecnie Wojewódzka Biblioteka Publiczna);

Biblioteka Ossolińskich: rpsy 7322 II i 7325 II Papiery Józefa Szujskiego; J.Szocki: Księgozbiór domowy Józefa Szujskiego. „Biuletyn Biblioteki Jagiellońskiej" 1989, s. 101-119; 1990, s. 33-124; I.Nowińska: Biblioteka domowa Józefa Szujskiego jako warsztat naukowy historyka praca magisterska (Instytut Bibliotekoznawstwa Uniwersytetu Wrocławskiego).

120) Świerzowicz Jan (4 IV 1887 Sanok - 4 I 1963 Mogilno)

nauczyciel, krytyk, historyk literatury;

24tys. tomów, w tym stare druki z XV-XVIII w., rękopisy;

głównie literatura polska, szczególnie epoki romantyzmu, Wielkiej Emigracji, literatura powszechna;

przechowywane w domu właściciela w Sanoku, udostępnione uczonym, ośrodkom uniwersyteckim, Instytutowi Badań Literackich;

Księga pamiątkowa Gimnazjum Meskiego w Sanoku 1888-1958. Kraków 1958, s. 51, 64-65, 92-93, 97, 104-105, 159, 171-177, 281-293, 335, 342; B.Jaśkiewicz: Świerzowicz Jan. w: Stownik pracowników ksiażki polskiej. Warszawa 1972, s. 892-893.

\section{1) Tarnowski Jan Feliks (6 V 1777 Dzików k. Tarnobrzegu -} 3 V 1842 tamże)

senator Królestwa Polskiego, historyk, ziemianin;

13-15 tys. dzieł, w tym ok. 8 tys. poloników, zbiór druków dysydenckich. 25 inkunabułów $i$ in. z siedzibą w Dzikowie;

7. różnych dziedzin wiedzy, literatura polityczna z czasów stanisławowskich; 
po śmierci właściciela zbiory przechowywane w Dzikowie, odziedziczone przez Jana Zdzisława Tarnowskiego;

Biblioteka Jagiellońska: rps 129/52 i 132/52 (Catalogue des livres estampes du C-te Jean Feliks Tarnowski); Biblioteka Ossolińskich: rps 1830/III (Katalog biblioteki Tarnowskich w Dzikowie przepisany dla Stanistawa Przylęckiego w roku 1850); K.Koźmian: Rys życia Jana Feliksa Tarnowskiego. „Biblioteka Ossolineum” 1884, s. 193-219; M.Kondek: Jan Feliks Tarnowski założyciel Biblioteki w Dzikowie - praca magisterska (Wyższa Szkoła Pedagogiczna, Kielce 1988).

\section{2) Tarnowski Jan Zdzislaw (5 VI 1862 - 24 XI 1937)}

polityk, członek Narodowego Komitetu, ziemianin;

30 tys. wol. (1926 r.), w tym wiele rękopisów (np. Pan Tadeusz), starych druków, rycin, albumów i in.;

z zakresu różnych dziedzin wiedzy;

ponad połowa księgozbioru spalona w pożarze zamku dzikowskiego w nocy z 22 na 23 XII 1927 r., w 1945 r. przekazane Bibliotece Jagiellońskiej, Bibliotece Narodowej i in.;

M.Marczak: Biblioteka Tarnowskich w Dzikowie. Kraków 1921; Biblioteka Narodowa w latach 1945-1956. Warszawa 1958, s. 58, 60.

\section{3) Tarnowski Juliusz (1 IV 1901 - 1940)}

ożeniony z Anną Branicka, ziemianin;

34 tys. dz. w 55 tys. wol. (1932 r.), w tym 1500 inkunabułów, wiele rękopisów z siedzibą w Suchej;

$\mathrm{z}$ różnych dziedzin wiedzy;

po 1945 r. 16528 tomów włączone do Biblioteki Ossolińskich we Wrocławiu, w 1948 r. ponad 5 tys. dz. w 8 tys. wol. - do Biblioteki Miejskiej w Gdańsku, rękopisy do Archiwum Głównego Akt Dawnych w Warszawie i Archiwum w Krakowie;

Biblioteka Ossolińskich: rpsy nr akc. 73/64 Katalog druków biblioteki w Suchej, t. 2; nr akc. 74/64: Spis szczegółowy dzieł, dyplomów, rękopisów w bibliotece na Frascati; a w Dziale Czasopism Biblioteki Ossolińskich: Spis czasopism biblioteki suskiej (maszynopis).

124) Wasylewski Stanisław (18 XII 1885 Stanisławów - 26 VII 1953 Opole)

bibliotekarz Biblioteki Czytelni Akademickiej, pracownik Biblioteki Zakładu Narodowego im. Ossolińskich, literat; 
najpierw ok. 1 tys. tomów (do 1915 r.), po 1918 r. do 8 tys. pozycji; z zakresu literatury, historii, pamiętnikarstwa i sztuki; spłonął w 1915 r., gromadzony po 1918 r., zniszczony w 1939 r.;

E.Chwalewik: Zbiory polskie. T. 1. Warszawa 1926, s. 428; Slownik pracowników ksiazki polskiej. Waszawa 1972, s. 939; Polscy pisarze wspólcześni. Warszawa 1977, s. 382-383.

125) Wolański Adam ( 17 X 1852 w. Werbeń k. Dubna - 22 III 1933 Kraków)

historyk, kolekcjoner;

spory księgozbiór, w tym stare druki, inkunabuły, rękopisy, dyplomy i numizmaty;

$\mathrm{z}$ różnych dziedzin wiedzy;

w 1906 r. ofiarowane Muzeum Narodowemu w Krakowie część zbiorów - dzieła sztuki i ok. 7,5 tys. starych druków;

Sprawozdanie Dyrekcji Muzeum Narodowego w Krakowie za r. 1906; Dar dla Muzeum Narodowego w Krakowie. Zbiory Mlynowskie, Chodkiewiczów. "Głos Narodu” 1920, nr 91, s. 103; Sprawozdanie Towarzystwa Naukowego we Lwowie 9: 1929, s. 215, 218.

126) Wszelaczyński Władysław (1847 w. Kupczyńce k. Lipowca $12 / 15$ ?/ II 1896 Lwów)

kompozytor, pedagog, prof. Konserwatorium we Lwowie;

bogaty księgozbiór, zbiór nut, rzadkich druków;

komplet polskich dzieł o muzyce;

część ofiarowana Bibliotece Towarzystwa Muzycznego we Lwowie, reszta sprzedana M.Hölzelowi i H.Dąbczańskiej (400 tomów);

E.Chwalewik: Zbiory polskie. T. 1. Warszawa 1926, s. 389.

\section{7) Zarewicz Stanisław (1874 - 1931)}

kustosz Miejskiego Muzeum we Lwowie, bibliofil; ok. 2000 tomów;

z zakresu historii sztuki polskiej (zbiór katalogów wystaw i dziel sztuki polskiej), także obcej, przemysłu artystycznego w Polsce $\mathrm{i}$ historii kultury;

E.Chwalewik: Zbiory polskie. T. 1. Warszawa 1926, s. 429; B.Janusz: Zhiory Stanislawa Zarewicza we Lwowie. "Ziemia" 1912, nr 16, 
S. 252-255; F.Jaworski: Wśród starojytników. Stanistaw Zarewicz. „Na ziemi naszej" 1911, nr 1.

128) Zawiliński Roman ( 1 III 1855 w. Brzeziny, Ropczyce - 21X 1932 Kraków)

nauczyciel, dyrektor gimnazjum w Nowym Sączu, Krakowie i Tarnowie, redaktor, slawista, etnograf;

ok. 2000 tomów;

$\mathrm{z}$ różnych dziedzin wiedzy;

kilkaset tomów podarowane w 1902 r. Bibliotece Towarzystwa Literackiego im. A.Mickiewicza $w$ Tarnowie, następnie przeszły do Biblioteki Publicznej w Tarnowie, 700 tomów podarowane tejże, reszta sprzedana Bibliotece Uniwersytetu w Poznaniu;

Sprawozdanie z czynności Zarzadu Kola TSL w Tarnowie. 1908, s. 7, 11-12; 1913, s. 22; B.Jaśkiewicz: Z dziejów Miejskiej Biblioteki Publicznej im. J.Slowackiego w Tarnowie 1908-1968. Tarnów 1970, s. 56-58; $Z$ dziejów Miejskiej Biblioteki Publicznej im. J.Slowackiego w Tarnowie 1908-1968. Pod red. B.Jaśkiewicza. Tarnów 1970, s. 122-124.

129) Zieliński Ludwik (1808 w. Czepiele /Brody/ - 3 IV 1873 Lwów)

literat, księgarz, wydawca, ziemianin;

$2201 \mathrm{dz}$. w 5897 tomach - z siedzibą w majątku Lubycza Królewska (k. Rawy Ruskiej), rękopisy z XVI-XVII w.;

$\mathrm{z}$ zakresu historii heraldyki, filozofii, teologii, leopolitana, beletrysty$\mathrm{ka}$;

przewiezione w $1868 \mathrm{r}$. do Lwowa, po $1882 \mathrm{r}$. rozsprzedane, wiele rękopisów trafiło do J.Dunina-Borkowskiego, większość biblioteki do A.Czołowskiego i w 1892 r. do Biblioteki Archiwum Miejskiego we Lwowie;

W.K.Zieliński: Zhiory archiwalne ś.p. Ludiwka Zielińskiego we Lwowie. "Wiadomóści Bibliografic=ne Warszawskie” 1882, s. 68-70, 104-105.

\section{0) Zieliński Tomasz ( 1802 Kraków - 18 VI 1858 Kielce)}

urzędnik, komisarz policyjny w Warszawie, naczelnik powiatu w Kielcach; cach;

4 tys. dz., rękopisy, mapy, ryciny, czasopisma - z siedzibą w Kiel-

z zakresu głównie historii i literatury; 
odziedziczone po śmierci właściciela przez Aleksandra Bronikowskiego, następnie - przez jego brata - Wojciecha Bronikowskiego, część weszła do Biblioteki Czartoryskich w Krakowie;

K.Buczek: Z przeszłości Biblioteki i Muzeum XX. Czartoryskich. Kraków 1936, s. 8; J.Nowak-Dłużewski: Mecenat kulturalny krainy kieleckiej. „Cychry” 1946, nr 6, s. 3; J.Pazdur: Dzieje Kielc do 1863 roku. Wrocław 1967, s. 229; I.Jakimowicz: Tomasz Zieliński - kolekcjoner i mecenas - praca dokt. (Wydział Historyczny Uniwersytetu Warszawskiego).

131) Ziembicki Karol Witold (18 VIII 1874 Lwów - 19 X 1950 Wrocław)

lekarz, historyk medycyny, bibliotekarz w Szpitalu Kolejowym we Lwowie, dyrektor Biblioteki Wrocławskiej Akademii Medycznej;

15 tys. tomów;

głównie z zakresu przyrodoznawstwa, medycyny historii, łowiectwa; darowane (częściowo) PAU;

E.Chwalewik: Zbiory polskie. T. 1. Warszawa 1926, s. 429; B.Giędosz: Prof. dr Witold Ziembicki. „Przeglad Lekarski” 1951, s. 353-357.

132) Żebrowski Teofil (5 IV 1800 Wojnicz nad Dunajcem - 5 II 1887 Kraków)

matematyk, bibliograf,członek Akademii Umiejętności;

2039 pozycji;

matematyczno-przyrodnicze;

sprzedane P.S.Moszyńskiemu i J.K.Działyńskiemu do Biblioteki Kórnickiej;

J.Dużyk, A.Trzederow: Zagadnienie opieki nad zabytkami w dzialalności TNK. "Roczniki Biblioteczne PAN” Kraków 3: 1957, s. 201-275. 


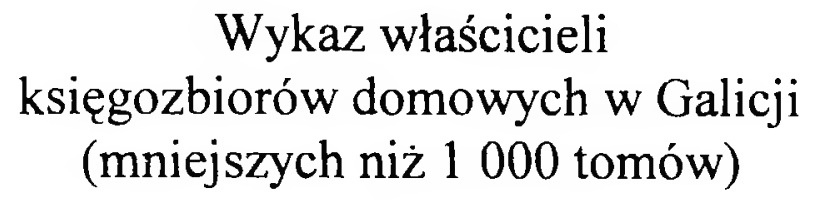

1) Czapski Emeryk-Hutten (17 XI 1828 Stańków k. Mińska - 23 VII 1896 Kraków)

archeolog, numizmatyk, fundator muzeów i bibliotek;

855 dzieł, w tym 329 druków z epoki jagiellońskiej, rękopisy, 270 autografów;

historia;

podstawa Muzeum Czapskich;

M.Gumowski: Wspomnienia numizmatyka. Przewodnik po Muzeum Czapskich. Kraków 1966, s. 31-44.

2) Czerwiakowski Józef Rafał (24 X 1743 pod Pińskiem - 5 VI 1816 Kraków)

pijar, profesor Akademii Krakowskiej;

549 książek przeważnie z II poł. XVIII w.;

głównie medycyna;

zapisane Akademii Krakowskiej;

K.Opałek: Myśl Oświecenia w Krakowie. Kraków 1955.

3) Dargun Lothar (1853 - 1893)

prawnik, socjolog, ekonomista, prof. historii prawa na Uniwersytecie Jagiellońskim;

210 dzieł i 227 broszur;

prawo;

książi po śmierci właściciela nabyły Biblioteka Jagiellońska, Biblioteka Uniwersytetu we Lwowie, Biblioteka Seminarium Prawa w Krakowie i Lwowie;

W.Jabłońska: Inwentarze i katalogi biblioteczne w Zbiorach rękopiśmiennych Biblioteki Zakładu Narodowego im. Ossolińskich. „Ze skarbca kultury" Wrocław 1969, s. 120-121.

4) Darowski Mieczyslaw, Weryha - ojciec (25 III 1810 w. Jurowce, pow. Sanok - 27 II 1889 Kraków)

ziemianin, działacz polityczny i społeczny, założyciel Stowarzyszenia Rzemieślników „Gwiazda”; 
ok 480 woluminów (152 dzieła), w tym stare druki z XVI-XVIII w., rękopisy;

historia, literatura, filozofia (francuskie);

częściowo darowane Bibliotece Czytelni Akademickiej, pozostałe przeszly do Stowarzyszenia Rzemieślników „Gwiazda” we Lwowie;

Polski Slownik Biograficzny. T. 4, s. 441-443; W.Jabłońska: Inwentarze i katalogi biblioteczne w Zbiorach rękopiśmiennych Biblioteki Zakladu Narodowego im. Ossolinskich. "Ze skarbca kultury" Wrocław 1969, s. 121.

5) Darowski Mieczyslaw - syn (1840 - 1906?)

inżynier budownictwa kolejowego, ziemianin;

446 dzieł, w tym 111 pozycji w języku francuskim, czasopisma. kalendarze;

historia, literatura piękna, kolejnictwo, gospodarstwo domowe;

przekazane Bibliotece Zakładu Narodowego im. Ossolińskich;

W.Jabłońska: Inwentarze i katalogi biblioteczne $w$ Zbiorach rękopiśmiennych Biblioteki Zakladu Narodowego im. Ossolińskich. „Ze skarbca kultury" Wrocław 1969, s. 121-122.

6) Goldstein Maksymilian (ur. około 1885)

urzędnik bankowy, numizmatyk;

ponad 450 dzieł, katalogi aukcyjne, grafika;

głównie numizmatyka, w tym najważniejsze prace o greckiej i rzymskiej numizmatyce, judaica, rzadkie druki hebrajskie;

Słownik pracowników książki polskiej. Waszawa 1972, s. 275.

7) Grabowski Ambroży (1782 - 1863)

historyk, księgarz, antykwariusz, prezes Towarzystwa Przyjaciół Sztuk Pięknych;

120 tomów rękopisów, druki z XV-XVIII , 700 dzieł XVI-XVIII i 300 z XIX w.;

historyczno-literacki, cracoviana, religijne wydawnictwa, literatura, historia i in.;

nabyte przez W.Baworowskiego, rękopisy z 1912 roku przekazane archiwum miasta Krakowa, część zbiorów przejęta przez Ossolineum;

E.Chwalewik: Zbiory polskie. T. 1. Warszawa 1926, s. 182; W.Jabłońska: Inwentarze i katalogi biblioteczne $w$ Zbiorach ręopi- 
śmiennych Biblioteki Zakladu Narodowego im. Ossolińskich. „Ze skarbca kultury" Wrocław 1969, s. 33-35.

8) Piwowarski Adam (24 XII 1809 Kraków - 29 I 1881 tamże)

inżynier, bibliotekarz;

501 dzieł w 892 tomach;

ofiarowane Bibliotece Jagiellońskiej;

S.Uruski, M.Tyrowicz, J.Bieliński: Królewski Uniwersytet Warszawski. T. 1. Warszawa 1907.

9) Podlacha Władysław (4 XII 1875 Bielany k. Krakowa - 20 XII 1951 Wrocław)

historyk sztuki, prof. Uniwersytetu Lwowskiego, badacz zdobnictwa książki;

ok. 430 pozycji;

historia, głównie historia sztuki;

zakupione przez Bibliotekę Muzeum Narodowego w Warszawie;

Polski Slownik Biograficzny. T. 27, 1 z., s. 112-115; E.Chwalewik: Zbiory polskie. T. 1. Warszawa 1926, s. 427.

10) Ptaśnik Jan (15 I 1876 w. Mikluszewice, pow. Bochnia - 22 II 1930 Lwów)

historyk, prof. Uniwersytetu Lwowskiego;

367 dzieł;

historia;

ofiarowane Bibliotece Miejskiej we Lwowie, spuścizna rękopiśmienna Bibliotece Zakładu Narodowego im. Ossolińskich;

Polski Slownik Biograficzny. T. 29, 2 z., s. 121, 303-307; Encyklopedia Wiedzy o Ksiqzice. Wrocław 1971, kol. 2034.

11) Przybylski Jacek Idzi (1 IX 1756 - 11 IX 1819 Kraków)

pisarz, prof. Uniwersytetu Jagiellońskiego;

494 dzieł w ponad 600 wol.;

cenne wydania pisarzy starożytnych i nowszych;

przekazane Bibliotece Jagiellońskiej;

Z.Ciechanowska: Relacje i opinie o księgozbiorze Biblioteki Jagiellońskiej na przelomie XVIII i XIX w. "Biuletyn Biblioteki .Jagiellońskiej" 1964, s. 81-101. 
12) Rydel Lucjan (17 V 1870 Kraków - 8 IV 1918 tamże)

poeta, bibliotekarz;

800 tomów, 200 czasopism i rękopisy;

różnotematyczne;

ofiarowne Bibliotece Jagiellońskiej;

J.Dużyk: Lucjan Rydel w nieznanych listach. Wrocław 1960.

13) Wójcikówna Bronisława (XIX w.)

800 tomów;

muzykologia w jęz. polskim, niemieckim i francuskim;

E.Chwalewik: Zbiory polskie. T. 1. Warszawa 1926, s. 428.

14) Zubrzycki Dionizy (1777 w. Batiatycze, pow. Źółkiew - 16 I 1862 Lwów)

historyk, archiwista, kierownik drukarni Instytutu Stauropigiałnego we Lwowie;

500 książek i broszur, rękopisy;

historia Rusi i literatura słowiańska, księgozbiór uważany współcześnie za najkompletniejszy w Galicji zbiór dzieł ruskich;

przekazany w $1858 \mathrm{r}$. bibliotece W.Baworowskiego;

Słownik pracowników książki polskiej. Waszawa 1972, s. 1027.

Wykaz pozostałych właścicieli księgozbiorów domowych w Galicji (informacja niepełna)

1. Als Rudolf (1858 - 1908) - adwokat i radny miejski w Rzeszowie, (jego księgozbiór liczył 1500 tomów).

2. Arctowski Henryk Bronisław (1871 - 1958) - geofizyk, geograf, podróżnik, twórca i dyrektor Instytutu Geofizyki i Meteorologii we Lwowie, prof. Uniwersytetu Lwowskiego (cenny księgozbiór z zakresu nauki o ziemi, zapisem testamentowym przekazany Uniwersytetowi Wrocławskiemu).

3. Badecki Karol Józef (1886 - 1953) - historyk literatury polskiej, archiwista, bibliograf, dyrektor Archiwum Akt Dawnych m. Lwowa, także Muzeum Narodowego im. Króla Jana III i Galerii Narodowej 
i Biblioteki Zakładu narodowego im. Ossolińskich, kustosz oddziału starych druków w Bibliotece Jagiellońskiej (zbiory własne z zakresu teorii literatury, leopolitana, monografie miast Małopolski Wschodniej, druki ulotne i wydawnictwa obyczajowo-satyryczne XVII i XVIII wieku).

4. Balaban Majer (1877 - 1943) - historyk, badacz dziejów drukarstwa, bibliograf, prof. Uniwersytetu Warszawskiego i Instytutu Judaistycznego w Warszawie (zbiory własne judaistyczne - druki dotyczące głównie Żydów Małopolskich, archiwalia).

5. Bandrowski Ernest Tytus (1853 - 1920) - chemik, prof. Akademii Techniczno-Przemysłowej w Krakowie i Uniwersytetu Jagiellońskiego, działacz społeczny, wiceprezydent Krakowa, (znaczny zbiór przeznaczony dla Biblioteki Muzeum Przemysłowego i Muzeum Etnograficznego w Krakowie, część jego została przeznaczona do biblioteki publicznej).

6. Baran Władysław (1882 - 1930) - bibliotekarz, aplikant w Archiwum Akt Dawnych Miasta Krakowa, dyrektor Biblioteki PAU, członek Towarzystwa Miłośników Książki w Krakowie, (zbiory z zakresu bibliografii, historii i literatury polskiej, broszury, ulotki z lat 19141918).

7. Barącz Roman (1856 - 1930) - prof. chirurgii, założyciel Polikliniki Powszechnej we Lwowie, (zbiory medyczne i z zakresu historii sztuki).

8. Bartoszewicz Kazimierz (1852 - 1930) - publicysta, redaktor, historyk, krytyk literacki, księgarz, (zbiór złożony z rękopisów, autografów, książek z historii, literatury).

9. Barwiński Aleksander (1847 - 1926) - pedagog, historyk i polityk ruski, prof. seminarium nauczycielskiego męskiego we Lwowie, poseł do Galicyjskiego Sejmu Krajowego, (zbiory własne ze szczególnym uwzględnieniem stasunków polsko-ruskich).

10.Bełza Władysław (1847 - 1913) - poeta, publicysta, bibliotekarz Zakładu Narodowego im. Ossolińskich, księgarz, (zbiory własne podarowane dla Biblioteki Zakładu Narodowego im. Ossolińskich, dla Działu Polskiego Biblioteki Muzeum Czackiego w Pradze).

11.Bernatowicz Grzegorz (XVIII/XIX) - rajca m. Lwowa, własny księgozbiór.

12.Biesiadecki Alfred (1839 - 1889) - lekarz chirurg, prof. Uniwersytetu Jagiellońskiego, (własny księgozbiór podarowany Towarzystwu J in i rzy Galicyjskich). 
13.Bilczewski Józef (1860 - 1923) - arcybiskup, metropolita lwowski, prof. teologii na Uniwersytecie Lwowskim, także dziekan i rektor, (księgozbiór znaczny).

14.Brodzki Eugeniusz, Łodzia (zm. 1842) - literat i wydawca lwowski, (ok. 2000 tomów).

15.Bruchnalska Maria z domu Nowotna (XIX/XX - zm. 1944) - powieściopisarka, założycielka Muzeum Polek we Lwowie, żona Wilhelma, (znaczny księgozbiór literacko-historyczny).

16.Bykowski Juliusz (Julian) Jaxa (1844 - 1915) - prof. i rektor Politechniki Lwowskiej, działacz społeczny i polityczny, (własny księgzbiór heraldyczny).

17.Bystrzycki Tadeusz (1889 - 1945) - inżynier architekt, księgarz, wiceprezydent $\mathrm{m}$. Przemyśla, członek założyciel Towarzystwa Przyjaciół Nauk w Przemyślu, (pokaźna biblioteka domowa).

18.Chodkiewicz Aleksander (1776 - 1838) - generał wojsk polskich, senator, dramaturg i chemik, (ok. 30000 tomów zniszczone w 1917/19, reszta - ok. 2000 dzieł i rękopisów oraz archiwalia ofiarowane Muzeum Narodowemu w Krakowie - Oddział Czapskich).

19.Chodynicki Ignacy (1786 - 1847) - ksiądz karmelita, historyk, bibliograf, (duży własny księgozbiór).

20.Chrzanowski Edward (1843 - 1922) - działacz polityczny i społeczny, ziemianin, (ok. 5 tys. tomów, w tym 9 inkunabułów i 50 rękopisów oddane w depozyt Bibliotece Zakładu Narodowego im. Ossolińskich).

21.Czarnecki Zygmunt (1823 - 1908) - ziemianin, (ok. 10000 tomów, sprzedane dla Biblioteki Baworowskich).

22.Darowski Mieczysław, Weryha (1810 - 1889) - działacz polityczny i społeczny, (ok. 1200 tomów, ofiarowane Bibliotece Zakładu Narodowego im. Ossolińskich).

23. Dubiecki Mateusz Władysław (1760 - 1845) - ksiądz, poeta, (pokaźny zbiór, z którego rękopisy zostały ofiarowane Bibliotece Szkoły Głównej w Krakowie w 1811 roku, zaś książki uległy rozproszeniu).

24. Estreicher Stanisław (1869 - 1939) - historyk prawa, bibliograf, prof. i rektor Uniwersytetu Jagiellońskiego (liczny zbiór).

25.Finkel Ludwik (1858 - 1930) - historyk, prof. i rektor Uniwersytetu Lwowskiego, bibliograf, redaktor "Kwartalnika Historycznego", (bogaty księgozbiór z zakresu historii: źródła i opracowania, podarowany Bibliotece Publicznej Towarzystwa Szkoły Ludowej w Tarnopo- 
lu, dzięki czemu powstała w ten sposób Biblioteka im. Ludwika Finkla).

26.Galli Edward Marian (1816 - 1893) - lekarz, literat, (ok. 8 tys. tomów, z których część zgnięła, reszta - 1518 dzieł polskich i 1498 obcych przekazane Bibliotece Jagiellońskiej).

27. Gębarowicz Mieczysław (ur. 1893) - historyk sztuki, (podręczna biblioteka historyczno-literacka).

28. Glowacki Michał Stanisław, pseud. Świętopełk (1804 - 1846) ksiądz, badacz poezji ludowej (ok. 1817 tomów).

29.Godebski Franciszek Ksawery (1801 - 1869) - pisarz, działacz polityczny, bibliotekarz, bibliograf, (kilka tysięcy dzieł).

30.Gomulicki Wiktor Teofil (1848 - 1919) - literat, publicysta, duży księgozbiór).

31. Górski Władysław, Pobóg (1822 - 1902) - historyk, ziemianin, (ponad 3 tys. tomów - czéść ofiarowana Bibliotece Jagiellońskiej).

32. Halaciński Kazimierz Ferdynand (11 I 1878 - 26 II 1930) - bibliofil, zbieracz ekslibrisów, działacz Towarzystwa Miłośników Książki w Krakowie, (bogaty zbiór ekslibrisów, wzorów opraw książkowych i in.).

33.Hartleb Kazimierz (1886 - 1951) - historyk kultury, bibliograf, bibliotekarz Biblioteki Uniwersyteckiej we Lwowie, prof. Uniwersytetu Toruńskiego, (własna biblioteka domowa).

34. Hirschberg Aleksander (1847 - 1907) - historyk, bibliotekarz, bibliofil, prezes Towarzystwa Oświaty Ludowej we Lwowie, (bogata biblioteka domowa).

35.Jabloński Kajetan (1815 - 1896) - księgarz, nakładca we Lwowie, (duże zbiory, które przeszły na własność W.Fedorowicza w Oknie i Biblioteki Zakładu Narodowego im. Ossolińskich).

36.Jakubowicz Józef (1820 - 1883) - uczestnik walk z r. 1848 i 1863 , ziemianin, (bogaty księgozbiór zapisany Bibliotece Gimnazjalnej w Brzeżanach).

37.Janusz Bohdan (1887? - 5 XI 1930) - archeolog, etnograf, publicysta, bibliofil, (cenne zbiory dotyczace prehistorii Lwowa i Podola, armenica po śmierci właściciela nabyte przez Zwiazzek Ormian we Lwowie dla utworzonej biblioteki archidiecezjalnej).

38.Jurystowski Tadeusz (1873 - 1930) - księgarz, bibliofil, członek Zarządu Towarzystwa Miłośników Książki, (bogaty zbiór okładek graficznych książek). 
39.Juszyński Michał (1760 - 1830) - ksiądz, nauczyciel, poeta, bibliograf, (duża biblioteka własna, która przeszła na własność Tarnowskich w Dzikowie).

40.Kamiński Jan Nepomucen Michał (1777 - 1855) - założyciel i dyrektor teatru lwowskiego, aktor, dramaturg, poeta i dziennikarz, (księgozbiór zawierający niemiecką literaturę dramatyczną XVIII-XIX w., ofiarowany Bibliotece Miejskiej w Stanisławowie).

41.Kamiński Julian Aleksander (1805 - 1860) - archiwista, wydawca, pisarz, bibliograf, bibliotekarz Zakładu Narodowego im. Ossolińskich, (duży księgozbiór ofiarowany Bibliotece Towarzystwa Gospodarskiego Galicyjskiego we Lwowie).

42.Klodziński Adam (1795 - 1858) - nauczyciel, dyrektor Zakładu Narodowego im. Ossolińskich, (księgozbiór podarowany Ossolineum).

43.Kohn Józef (XIX w.) - zbiór w kilku tysiącach tomów głównie z filozofii.

44.Konopka Stanisław (1783 - 1850) - major wojsk polskich, członek Stanów Galicyjskich, ziemianin, (ok. 1 tys. tomów, połączone w 1893 roku z biblioteką Konopków w Tomaszowicach k. Krakowa razem 16 tys. dzieł, ok. 12 tys. archiwaliów i in.).

45.Kotula Rudolf Gabriel (1875 - 1940) - dyrektor Biblioteki Uniwersyteckiej we Lwowie i Biblioteki Fundacji hr. Wiktora Baworowskiego, (duży księgozbiór własny z zakresu historii, historii literatury, bibliografii, bibliotekoznawstwa, włączony do Biblioteki Baworowskich).

46.Krček Franciszek (1869 - 1916) - filolog, etnograf, bibliograf, docent Uniwersytetu Lwowskiego, (cenny księgozbiór własny: druki, rękopisy dotyczące głównie filologii słowiańskiej, zakupiony w 1919 roku przez Bibliotekę Uniwersytetu w Poznaniu).

47.Kudurewicz Florian (1766 - 1834) - prof. teologii, ksiądz unicki, prof. w Szkole Głównej w Krakowie, (własny księgozbiór przekazany testamentem m.in. Bibliotece Jagiellońskiej, profesorowi Uniwersytetu Jagiellońskiego - Karolowi Mecherzyńskiemu).

48.Kunzek Henryk (1871 - 1928) - lekarz, rzeźbiarz, prof. Akademii Sztuk Pięknych w Krakowie, (posiadał znaczny księgozbiór z zakresu sztuki, kultury, filozofii, historii, literatury pięknej polskiej i niemieckiej).

49.Łepkowski Józef (1826 - 1894) - archeolog, pisarz, rektor Uniwersytetu Jagiellońskigo, działacz narodowy, bibliotekarz, (zgromadził bibliotekị rłożona 7. dzieł z. zakresu historii, archeologii, cracoviana, przesła na własność biblioteki K.Przeździeckiego w Warszawie). 
50. Malecki Antoni (1821 - 1913) - historyk literatury, prof. Uniwersytetu w Krakowie, Innsbrucku i we Lwowie, poseł na Sejm Krajowy Galicyjski, (księgozbiór, m. in. rękopisy J.Słowackiego, ofiarowany Bibliotece Zakładu Narodowego im. Ossolińskich).

51.Mecherzyński Karol (1800 - 1881) - historyk literatury, pedagog, prof. Uniwersytetu Jagiellońskiego, (zasobna biblioteka domowa o charakterze naukowym, uległa zniszczeniu w czasie pożaru).

52.Nargielewicz Jan (zm. 1886) - ziemianin, (20 tys. tomów, z tego 3684 dzieł w 8790 wol. ofiarowane Bibliotece Zakładu Narodowego im. Ossolińskich).

53. Nowakowski Edward, w zakonie Wacław, pseud. Wacław z Sulgostowa (1829 - 1903) - kapucyn, historyk, bibliotekarz, bibliograf, (bogata biblioteka w siberiaca).

54.Nowakowski Franciszek Kandyd (1813 - 1881) - bibliotekarz u Branickich w Suchej, (własna biblioteka przekazana w części do suskiej i w części do Biblioteki Jagiellońskiej).

55.Pawlicki Stefan (1839 - 1916) - ksiądz zmartwychwstaniec, prof. uniwersytecki, (5 605 dzieł w 9919 tomach - ofiarowane Bibliotece Jagiellońskiej).

56.Peter Ludwik (1855? - 1895) - muzyk, historyk muzyki, bibliograf, (cenne wydawnictwa nutowe i rękopisy w części przekazane Bibliotece Jagiellońskiej).

57.Pieniążek Jarosław, Odrowąż (1853 - 1920) - aktor, dziennikarz, urzędnik, (duży zbiór, m.in. zdjęć fotograficznych, przekazany Muzeum $\mathrm{m}$. Lwowa).

58.Pietrzycki Edward (1825 - 1908) - urzędnik, działacz Towarzystwa SL, (kilka tysięcy tomów ofiarowane Bibliotece Archiwum Miejskiego we Lwowie i założonej w 1906 r. Publicznej Bibliotece Lwowskiego Związku Okręgowego Towarzystwa SL).

59.Piniński Leon (1857 - 1938) - prawnik, prof. i rekotr Uniwersytetu Lwowskiego, historyk sztuki, namiestnik Galicji, ziemianin, (zasobna biblioteka złożona ze starych druków, rękopisów, modlitewników, mszałów i in., przekazana testamentem Zakładowi Narodowemu im. Ossolińskich).

60.Poller Józef Michał (1831 - 1902) - oficer, bibliotekarz, (liczny zbiór podarowany Bibliotece Jagiellońskiej).

61.Przylęcki Stanisław (1805 - 1866) - historyk, bibliotekarz, bibliograf, edytor, ziemianin, (cenna biblioteka własna złożona ze starych druków, rękopisów). 
62. Rolle Antonii Józef, pseud. Dr Antoni J. (1830 - 1894) - lekarz, (duża biblioteka, $\mathrm{z}$ niej ponad 1 tys. tomów przekazane Czytelni Akademickiej we Lwowie).

63.Rostafiński Józef Tomasz (1850 - 1928) - botanik, prof. Uniwersytetu Jagiellońskiego, (własny księgozbiór domowy).

64.Rościszewski Adam Junosza (1777 - 1844) - słowianofil, bibliograf, ziemianin,(księgozbiór złożony z rycin, map, rękopisów, druków - literatura).

65.Rutowski Tadeusz (1850 - 1918) - prezydent m. Lwowa, działacz społeczno-polityczny, (księgozbiór złożony głównie z książek o tematyce społeczno-politycznej i ekonomicznej).

66.Scipio del Campo Jan Karol ( 1801 - 1890) - ksiądz, senator Rzeczypospolitej Krakowskiej, (ok. 1 tys. tomów przekazane bibliotece dzikowskiej J.F. Tarnowskiego)

67. Siwiec Leopold (1875 - 1944) - urzędnik pocztowy, (pokaźna biblioteka złożona z dzieł o komunikacji, poczcie, cenne druki obcojęzyczne dotyczace historii poczty).

68. Slotwiński Konstanty (1793 - 1846) - urzędnik, bibliotekarz, prawnik, dyrektor Biblioteki Zakładu Narodowego im. Ossolińskich, ziemianin, (cenny księgozbiór domowy).

69.Solski Tadeusz (1884 - 1966) - prawnik, urzędnik, bibliotekarz, bankowiec, kustosz Biblioteki Zakładu Narodowego im. Ossolińskich, (bogaty księgozbiór złożony z prac dotyczących ekslibrisu, polskiego pieniądza papierowego, leopolitanów, ekslibrisów - ok. 14 tysięcy).

70.Stankiewicz Maurycy Michal (1857 - 1892) - księgarz, bibliograf, czlonek Komisji Antropologicznej Akademii Umiejętności i in. towarzystw naukowych, (zbiór złożony z lithuaników i wydawnictw dotyczących literatury polskiej i bibliografii).

71.Sznejder Antoni (XIX w.) - zbiory własne liczyły 3 tysiące dziel, także archiwum.

72.Świeżawski Ernest (1843 - 1919) - krytyk literacki (2 000 tomów przekazane Bibliotece Publicznej w Zakopanem).

73. Tyszkowski Kazimierz (1894 - 1940) - historyk, bibliotekarz, bibliograf, kustosz Oddziału Rękopisów Biblioteki Zakładu Narodowego im. Ossolińskich, ziemianin, (zbiory własne z zakresu historii sztuki, historii, bibliografii).

74.Walewski Cyprian (1820 - 1873) - bibliograf, ziemianin, (10 $847 \mathrm{dz}$., 158 rękopisow, 235 map, 700 rycin $i$ in. ofiarowane Bibliotece Akademii Umiejętności w Krakowie). 
75.Walewski Tadeusz (XIX w.) - wicemarszałek stanowy Królestwa Galicji i Lodomerii, działacz społeczno-kulturalny i literat, (własna biblioteka).

76.Wierczyński-Vrtel Stefan (1886 - 1963) - historyk literatury, prof. Uniwersytetu, bibliotekarz, bibliograf, (zbiór złożony z prac dotyczących historii, bibliografii polskiej).

77.Wyslouch Bolesław ( 1855 - 1937) - działacz ruchu ludowego, senator, publicysta, nakładca, (biblioteka złożona z dzieł z zakresu historii, sztuki, ekslibrisy).

78.Wysocki August (zm. 1871 Lwów) - adwokat, bibliofil; zbiór własny liczył kilkanaści tysięcy tomów z zakresu prawa, historii, literatury pięknej.

79.Wysocki Wladyslaw Tadeusz (1887 - 1941) - publicysta, bibliotekarz, bibliograf, słowianoznawca, kustosz Biblioteki Zakładu Narodowego im. Ossolińskich, (cenny księgozbiór, głównie bibliografie, także z. zakresu bibliologii i słowianoznawstwa). 